
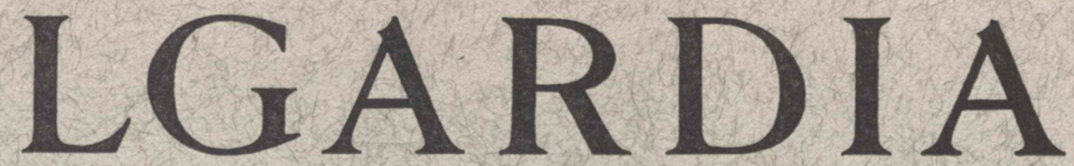

A Journal of Agricultural Science Published by the California Agricultural Experiment Station

\title{
STUDIES OF MICROÖRGANISMS PATHOGENIC TO THE SOD WEBWORM
}

\author{
IRVIN M. HALL
}


Four microörganisms - a spore-forming bacterium, two strains of a fungus, and a microsporidian - were tested as biological agents for the control of the sod webworm, Crambus bonifatellus (Hulst). Results of laboratory and greenhouse tests, or, with the microsporidian, very limited field tests, indicate that the bacterium is the most promising of these. Further tests under natural conditions are necessary to establish their practical value.

The bacterium, Bacillus thuringiensis Berliner, was the fastest-acting and was almost 100 per cent effective against all instars of the sodwebworm larva. Its spores can readily be produced in quantity on artificial media, can be stored dry for long periods with little loss of virulence, and, since they are miscible with water, can easily be prepared as a suspension for spraying. Laboratory tests indicate that they would also be effective if prepared as a dust. Humidity and temperature requirements for germination are not stringent.

Both strains of the fungus, Beauveria bassiana (Balsamo), were fairly fast-acting and were almost 100 per cent effective against early instars of the webworm larva. The strain isolated from Crambus sp. was more effective against late instars than that isolated from the European corn borer, but neither was completely effective. As with the bacillus, the fungus spores can readily be produced in quantity on artificial media and can be stored dry for some time. Since, in contrast with the bacillus spores, they are not miscible with water, a spore suspension for spraying was prepared with blood albumen spreader; but it proved less effective than a dust prepared with talc. The spores require high humidity and fairly high temperatures for germination-requirements that limit the practical applications of this agent.

The microsporidian, Nosema infesta Hall, is an obligate parasite, and no satisfactory method of producing its spores in quantity was found; yet heary concentrations are required in field applications. It is slowacting and in limited field tests gave very low morbidity and mortality rates. Hence it seems ruled out as a possible agent in the control of the sod webworm, at least in a short-term program.

The effect of these microörganisms on beneficial insects is not known. None of them is believed to be dangerous to man, though sensitivity to the fungus spores may be acquired by inhaling large quantities of them. 


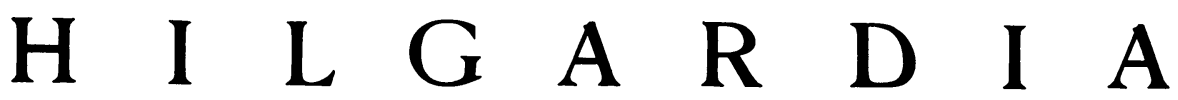

A Journal of Agricultural Science Published by

the California Agricultural Experiment Station

VoL. 22

February, 1954

No. 15

\section{STUDIES OF MICROÖRGANISMS PATHOGENIC TO THE SOD WEBWORM ${ }^{1}$}

\author{
IRVIN M. HALL ${ }^{2}$
}

\section{INTRODUCTION}

MANY SPECIES of the genus Crambus Fabricius are recognized as major insect pests of grasses and grains. The genus is distributed throughout the world, and about 100 species are known to occur in North America. Since 1929, when widespread damage was reported throughout North America, the sod webworms have become known as important lawn pests. According to Bohart (1947), of the eighteen species reported from California, only two, the fawncolored lawn moth, C. bonifatellus (Hulst), and the silver-barred lawn moth, C. sperryellus Knots, are known to infest lawns.

Sod-webworm damage is difficult to diagnose and is often confused with other troubles. To identify lawn-moth injury, Bohart used the following eriteria: (1) Irregular brown patches are usually present instead of the circular spots associated with fungus. (2) Shortness or uneven height of grass near dead areas evidences larval feeding. (3) Numerous adult moths are present, resting in the shrubbery or under window ledges near the lawn. (4) Abundant predatory yellowjackets or parasitic wasps and flies indicate a high population of host larvae. Green areas near damaged sections of the lawn may be tested with a pyrethrum solution. This solution is prepared from a watermiscible extract containing 2 per cent pyrethrins, diluted 1 part to 400 parts of water. The mixture is applied to grass with a sprinkling can at the rate of 1 gallon per square yard. Bohart states that the appearance of at least 100 Crambus larvae to the square yard of lawn within 10 minutes after application of the pyrethrum solution indicates a serious infestation.

Practical methods of control, as advocated today, involve the use of insecticides. According to Bohart, insecticides, when applied in sufficient concentration, give temporary control of Crambus infestations. The materials are pyrethrum and rotenone products, dichloroethyl ether, and acid lead arsenate. Only the latter prevented reinfestation. Ebeling, Pence, and Kimball (1947) found DDT to be promising for the control of sod webworms. Chlor-

\footnotetext{
${ }^{1}$ Contribution from the Laboratory in Insect Pathology, Department of Biological Control, College of Agriculture, University of California, Berkeley.

${ }^{2}$ Junior Entomologist in the Experiment Station, Riverside.
} 
dane, DDT, and toxaphene are recommended for control of Crambus larvae in lawns by Jefferson and Eads $(1951,1952)$.

Lawn moths have numerous natural enemies. Bohart (1947) reports that although many species appear to be casual predators, a few always accompany lawn moths and may assist in limiting their activities and in checking the reinfestation of treated lawns.

There are only a few reports of diseases of species of Crambus. Bohart suggests that larval diseases may occasionally have been responsible for sudden decreases in sod webworm populations that could not be attributed to other causes. He reports that four species of bacteria were isolated from diseased laboratory-reared larvae. These were a small Gram-negative rodprobably Escherichia coli (Migula) - a short and wider Gram-negative rod, a species of Staphylococcus, and a species of Streptococcus. He states that broth cultures of the four bacteria were poured over grass which was then fed to Crambus larvae. No increase in mortality took place as compared with larvae fed upon untreated grass.

Three species of pathogenic fungi have been reported. Ainslee (1923) mentions that a species of Isaria has been observed attacking Crambus mutabilis Clemens in Tennessee. A species of Empusa was reported to have caused death to crambid larvae in Ontario, Canada, by Stirrett and Arnott (1932). Noble (1932) reports the presence of Beauveria bassiana (Balsamo) in populations of undetermined species of Crambus in Indiana. A strain of B. bassiana was isolated by C. G. Thompson of the Laboratory of Insect Pathology (Department of Biological Control, University of California) from dead larvae of an unidentified species of Crambus collected in Oregon.

A microsporidian, Nosema infesta Hall, was isolated by the writer from laboratory-reared larvae and pupae of Crambus bonifatellus in 1948. This organism has been found since in crambid populations in El Cerrito, and Berkeley, California. It has been described completely in another publication (Hall, 1952).

Two of the above-mentioned microörganisms, the strain of Beauveria bassiana received from Oregon and the microsporidian, will be discussed at much greater length later in this report in conjunction with tests to determine their usefulness as biological agents for controlling the sod webworm. Other organisms evaluated for their control potentialities are a strain of Beauveria bassiana from the European corn borer and a strain of the sporeforming bacterium, Bacillus thuringiensis Berliner from the Mediterranean flour moth, Ephestia kuhniella Zeller. The report is separated into three sections according to the microörganism concerned. 


\section{NOSEMA INFESTA}

\section{Production of Microsporidian Material}

Difficulties were encountered in attempts to rear the sod webworm in large numbers for the cultivation of the microsporidian, Nosema infesta, an obligate parasite. Because of this, efforts were made to find one or more new hosts which could be reared in mass in the insectary or in the laboratory. Cross-infection tests indicated that two insectary-reared insects, the potato tuberworm, Gnorimoschema operculella (Zeller), and the buckeye caterpillar, Junonia coenia Hübner, were suitable alternate hosts.

Production of Nosema infesta was undertaken by infecting mass-reared buckeye eaterpillars. Later an attempt was made to utilize the potato tuberworm as host, using the insectary method described by Finney, Flanders, and Smith (1947). Certain modifications were made in this method to bring about infection of the tuberworms by the parasites.

Following superficial puncturing, the mature egg-sized potatoes were dipped in a suspension of the microsporidian spores (concentration about 50 million spores per $\mathrm{ml}$ ). As the young larvae penetrated the potatoes, they ingested spores and became infected. Mature infected larvae were collected and ground in distilled water in a Waring blendor. This solution was then strained through a double layer of cheesecloth to remove the large particles. The resultant spore suspension was stored in the refrigerator.

The hope of a heavy yield of spores using the potato tuberworm as a host never materialized. After production was well under way, the yield began to drop. Operations were stopped when the quantity of spores produced became less than the amount used to bring about the infection of the larvae. It is to be noted that the spores used to infect, with the exception of those used at the beginning of production, had been passed through the potato tuberworm. It is possible that repeated passage of such an organism through a host other than its natural one may reduce its virulence toward such a host.

\section{Laboratory Experiments with Nosema infesta}

Storage of Spores. The most convenient way to store quantities of microsporidian spores is to keep the flasks of aqueous spore suspension under refrigeration at $5{ }^{\circ} \mathrm{C}$. Unfortunately, however, since the suspension also contains parts of the bodies of the tuberworm host, the bacteria that are present increase rapidly in spite of the low temperature. An effort was made to find other methods of storage which would hold down the bacterial contamination and at the same time to determine the longevity of the spores under various conditions of storage.

Quantities of spores were placed in storage under the following conditions:

1. Dry slides (at room temperature)

2. Water suspension in refrigerator $\left(5^{\circ} \mathrm{C}\right)$

3. Water suspension in deep freeze $\left(-30^{\circ} \mathrm{C}\right)$

4. Water suspension quick frozen ( 95 per cent ethyl alcohol—dry ice) and stored in deep freeze

5. Damp soil at room temperature

Tests were made to determine infectivity on suitable host insects after 
$1,2,3$, and 4 weeks, and 2, 3, 4, 5, 6, 9, and 12 months. The insects used in the infectivity tests were the California oakworm, Phryganidia californica Packard, and the buckeye caterpillar. Which insect was used depended upon availability at the time of each test.

In conducting the infectivity tests, twenty-five containers were set up for each storage period, each container with 5 second- and third-instar larvae. Five of these containers were maintained as uninfected controls. The remainder were divided into five groups of four containers each. The 20 larvae

TABLE 1

RETENTION OF VIRULENCE* OF NOSEMA INFESTA SPORES AFTER STORAGE FOR VARIOUS PERIODS AND UNDER VARIOUS CONDITIONS

\begin{tabular}{|c|c|c|c|c|c|c|c|c|c|c|c|}
\hline \multirow{2}{*}{ Method of storage } & \multicolumn{11}{|c|}{ Percentage infection in 5 test larvae after: } \\
\hline & $\begin{array}{c}1 \\
\text { wk. }\end{array}$ & $\begin{array}{c}2 \\
\text { wks. }\end{array}$ & \begin{tabular}{c|}
3 \\
wks.
\end{tabular} & $\begin{array}{c}4 \\
\text { wks. }\end{array}$ & $\begin{array}{c}2 \\
\text { mos. }\end{array}$ & $\begin{array}{c}3 \\
\text { mos. }\end{array}$ & $\begin{array}{c}\mathbf{4} \\
\text { mos. }\end{array}$ & $\begin{array}{c}5 \\
\text { mos. }\end{array}$ & $\begin{array}{c}6 \\
\text { mos. }\end{array}$ & $\begin{array}{c}9 \\
\text { mos. }\end{array}$ & $\begin{array}{c}12 \\
\text { mos. }\end{array}$ \\
\hline \multicolumn{12}{|c|}{ First test } \\
\hline Dry slides; room temperature..... & 50 & 100 & 100 & 0 & 17 & 0 & 0 & 0 & 0 & 0 & 0 \\
\hline \multicolumn{12}{|l|}{ Water suspension: } \\
\hline In deep freeze. . . . . . . & 100 & 100 & 100 & 100 & $\begin{array}{l}85 \\
70\end{array}$ & $\begin{array}{l}88 \\
38\end{array}$ & 80 & $\begin{array}{l}100 \\
100\end{array}$ & $\begin{array}{r}60 \\
100\end{array}$ & $\begin{array}{r}0 \\
60\end{array}$ & $\begin{array}{r}0 \\
20\end{array}$ \\
\hline Quick frozen . . . . . . . . . . & $1 \mathrm{CO}$ & 0 & 38 & 0 & 0 & 0 & 0 & 0 & 0 & 0 & 0 \\
\hline Damp soil; room temperature. & 100 & 100 & 100 & 100 & 75 & 75 & 40 & 100 & 0 & 0 & 0 \\
\hline Negative control ........... & 0 & 0 & 0 & 0 & 0 & 0 & 0 & 0 & 0 & 0 & 0 \\
\hline
\end{tabular}

Second test

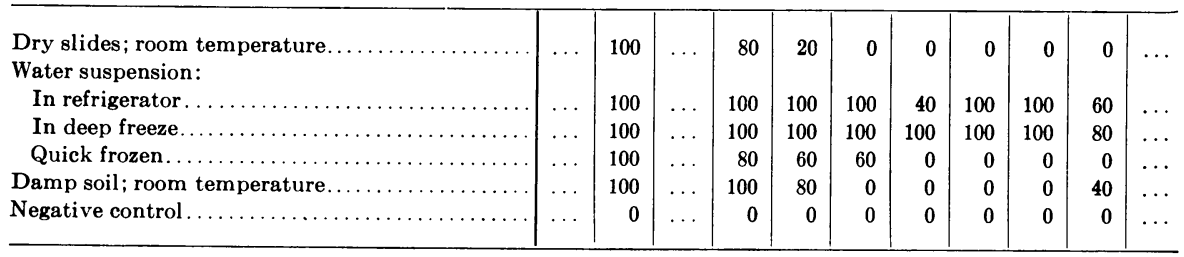

* Phrygandia californica used in some tests, Junonia coenia in others. All tests for a given period used the same species.

in each group were fed leaves which had been dipped in a water suspension of spores from one of the five methods of storage. After about 2 weeks, smears of 5 larvae selected at random from each group were examined for the presence of spores. The results are presented in the upper section of table 1.

To check the results of the above experiment, a second longevity test was set up. The same methods of storage were tested after periods of 2 and 4 weeks, and 2, 3, 4, 5, 6, and 9 months. The results are presented in the lower section of table 1 .

From the data (table 1), it appears that the method in which a water suspension of the spores is held in the deep freeze is the best for storage of spores of this microsporidian. The spores seem to survive longer with this method than with the water suspension in the refrigerator. Also, bacterial growth, which offers a serious problem in storage of spore suspensions in the refrigerator, cannot occur when the suspensions are frozen. 
Insects Susceptible to Oral Infection. A series of infectivity tests were conducted on available local insects, both insectary-reared and field-collected. In each test, small groups of larvae of a single species were allowed to feed on leaves contaminated with spores of Nosema infesta. Other groups of larvae were maintained as controls. After 10 to 12 days, the control and test larvae were examined for the presence of spores. Each experiment was considered to give positive results when the test larvae were found to contain spores while the control insects were not infected. If the control larvae were infected, the test was discarded as inconclusive. By the use of these infectivity tests, a number of larvae of other insects than the sod webworm were found to be susceptible to oral infection by Nosema infesta. In addition to the buckeye caterpillar and potato tuberworm, previously mentioned, these include: California oakworm, Phryganidia californica Packard; alfalfa caterpillar, Colias philodice eurytheme Boisduval; imported cabbageworm, Pieris rapae (Linnaeus); larvae of the malva butterfly, Vanessa carye (Hübner); salt-marsh caterpillar, Estigmene acraea (Drury) ; beet webworm, Loxostege sticticalis (Linnaeus); granulate cutworm, Feltia subterranea (Fabricius); beet armyworn, Laphygma exigua (Hübner); armyworm, Cirphis unipuncta (Haworth); Heliothis phloxophaga.

One other insect can be added to the list of host insects for Nosema infesta. This insect, the fiery skipper, Hylephila phylaeus Drury, has not been tested in the laboratory but almost 100 per cent infection has been observed in larvae collected from lawns in El Cerrito, California, where the microsporidian is known to be present in the sod-webworm population. Because of the high degree of parasitism, there is the possibility that the fiery skipper, instead of the lawn moth, may be the natural host for Nosema infesta.

Infection with Spore Suspensions of Varying Concentrations. A dilution test was set up to determine the effect on Crambus larvae of feeding on grass contaminated with Nosema spores from suspensions of known concentration. Spore suspensions of the following concentrations were tested: 50 million, 25 million, 10 million, 1 million, and $1 / 2$ million spores per ml. The four lower concentrations were prepared by diluting the 50 million spores per $\mathrm{ml}$ suspension, the concentration of which had been determined with the use of a haemacytometer.

The third-instar Crambus larvae used in the test were laboratory-reared from eggs obtained from field-collected adult females. All of the larvae were set up, 5 to a carton. The cartons used in the laboratory tests were $1 / 2$-pint paper containers with Petri-dish tops. Thirty larvae were maintained as controls and fed uncontaminated grass. Five groups of 30 larvae were used in the test. All of the larvae of a single group were fed grass which had been dipped in one of the spore suspensions. Only a few blades of contaminated grass were placed in each carton at the beginning of the test. On subsequent days, vials of uncontaminated grass were placed in each carton to keep available to the larvae a fresh supply of food. The results are presented in table 2.

It is apparent that higher concentrations of spores in the initial infection speed up the activity of the disease organisms. With the use of higher concentrations, the time for the insects to show effects of the disease is shortened 
and the mortality is increased. Concentrations of 10 million spores per $\mathrm{ml}$ and above produced high mortality. With concentrations of 1 million spores per $\mathrm{ml}$ and below, the mortality was much lower.

Many of the control larvae were infected with the microsporidian. As stated before, the larvae were reared from eggs obtained from field-collected females. The moths, collected in El Cerrito, California, were very likely infected and the protozoa passed on via the egg to the larvae. The percentage mortality in the control larvae was much lower than in the test insects.

TABLE 2

PERCENTAGE MORTALITY OF CRAMBUS BONIFATELLUS LARVAE AFTER FEEDING ON GRASS CONTAMINATED WITH KNOWN CONCENTRATIONS OF NOSEMA INFESTA SPORES

\begin{tabular}{|c|c|c|c|c|c|c|}
\hline \multirow{2}{*}{$\begin{array}{l}\text { Concentration, } \\
\text { spores } / \mathrm{ml}\end{array}$} & \multirow{2}{*}{$\begin{array}{c}\text { Total larvae } \\
\text { examined }\end{array}$} & \multicolumn{5}{|c|}{ Percentage mortality of larvae when examined on: } \\
\hline & & 8th day & 11th day & 15th day & 24th day & Total \\
\hline 50 million. & 21 & 19 & 52 & 24 & 5 & 100 \\
\hline 25 million. . & 19 & 11 & 42 & 47 & 0 & 100 \\
\hline 10 million. . & 16 & 0 & 44 & 37 & 19 & 100 \\
\hline 1 million... & 7 & 0 & 0 & 43 & 0 & 43 \\
\hline $1 / 2$ million...$\ldots \ldots \ldots$ & 11 & 0 & 18 & 0 & 45 & 63 \\
\hline $\mathbf{0}$ (control group) ............ & 15 & 0 & 7 & 0 & 60 & 67 \\
\hline
\end{tabular}

\section{Field Experiments with Nosema infesta}

A field test was conducted in the summer of 1949 in an effort to determine the possibilities of using Nosema infesta to reduce the population level of the sod webworm. The plot for this experiment was a lawn in Berkeley, California. When the lawn was first examined, many brown patches gave visible evidence of damage by lawn pests, and many Crambus adults were observed flying over the lawn. However, a weak solution of pyrethrum applied to border areas, as recommended by Bohart (1947), brought to the surface only one sod webworm, which indicates a very small larval population at that time.

The lawn was divided into two equal sections with the control area on the windward side for protection against contamination when the spores were applied. The area to be sprayed measured about 5 by 10 yards. One liter of spore suspension (concentration about 200 million spores per $\mathrm{ml}$ ) was diluted with 7 liters of water to make 8 liters of spray material (concentration about 25 million spores per ml). Application of this material was made with a Hudson garden sprayer. Approximately 4 billion spores were applied to each square yard of lawn.

One week later, a second application of spore material was made to one half the area sprayed previously. Eight liters of spore suspension (same concentration as before) was sprayed on the plot with approximately 8 billion spores applied to each square yard. Thus, the test area was divided into two parts. Test plot 1 had a concentration of 4 billion spores, test plot 2 12 billion spores per square yard. 
Since the total lawn area was limited, it was necessary to reduce the size of the areas tested with pyrethrum to small squares (about $1 / 2$ by $1 / 2$ yard). Two squares from each sprayed plot and the control area were treated with a weak pyrethrum solution every few days and the insects collected were examined for the presence of spores. A record was kept of the location of each pyrethrum-treated square to avoid repetition in the testing.

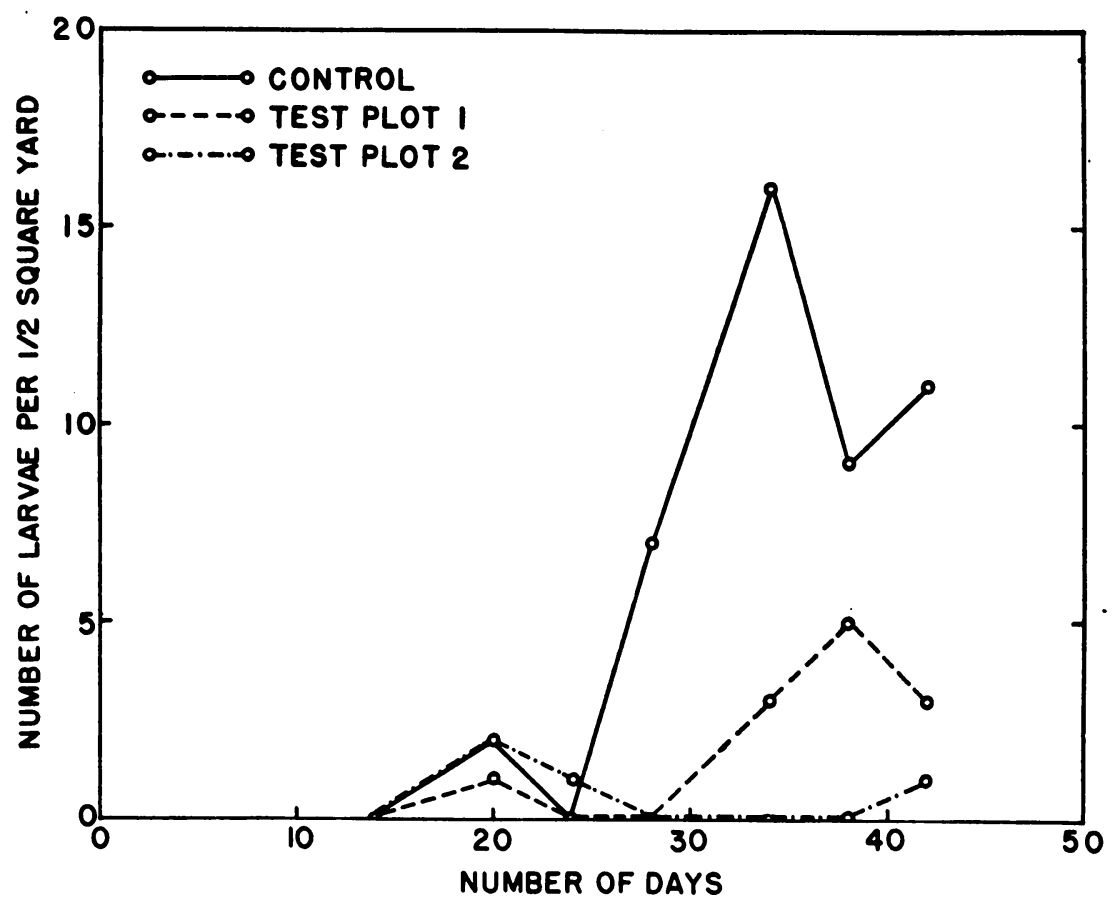

Fig. 1. The number of Crambus bonifatellus larvae per $\frac{1}{2}$ square yard of lawn in test (Nosema-treated) plots and control (untreated) plot of 1949 Nosema infesta field experiment.

The results are presented in figure 1. Although the sod-webworm population was very small, almost all of the larvae collected from the sprayed plots were found to contain quantities of spores, while most of those from the control plot contained no spores. The presence of some infected larvae in the control plot can be attributed to either migration of larvae from the sprayed areas or the natural occurrence of the microsporidian in the sod-webworm population. No significant differences were noticed between the plots sprayed with different concentrations of spores.

In the summer of 1950 , a field test was conducted on a lawn adjacent to the Brazilian Room in Tilden Regional Park, just east of Berkeley, California. Two 10 yard by 10 yard areas were marked off. One area was reserved as a control. The other area was sprayed with a spore suspension prepared by mixing 1 liter of spore suspension (concentration about 50 million spores 
per $\mathrm{ml}$ ) with 3 liters of water. Application was made with a Hudson garden sprayer. Approximately 500 million spores were applied to each square yard of lawn.

The sampling technique involved the application of a weak pyrethrum solution every few days to two $1 / 2$-square-yard areas from each plot and counting the Crambus larvae that were brought up within 15 minutes. The insects collected were examined in the laboratory for the presence of spores. A record was kept of the location of each pyrethrum-treated area to avoid repetition in the testing.

A second test was made at the same site on a similar plot. The procedure for this test was the same as for the previous one except that a 1-liter spore suspension of quadruple strength (concentration about 200 million spores per $\mathrm{ml}$ ) mixed with 7 liters of water was utilized. The increase in volume of mixture was made in an effort to obtain better coverage of the grass by the spores. Approximately 2 billion spores were applied to each square yard of lawn.

The results of these two tests were very poor. In both cases, the introduction of the microörganism brought about no reduction of the population level of the insect. Only about 2 per cent of the larvae recovered during the first test were found to contain spores. When the concentration of spores, was quadrupled, only slightly better than 3.5 per cent of the larvae recovered were found to be infected.

The results of the field tests conducted during 1949 and 1950 using the microsporidian indicate that high concentrations of spore material per unit of lawn area may be necessary to initiate an epizoötic in sod-webworm populations. This and the fact that spores of this obligate parasite are very diffcult to produce in quantity may rule out the use of Nosema infesta in microbial control of populations of Crambus in a short-term program. Such programs utilize agents which are capable of greatly reducing the insect populations present at the time of application.

Nosema infesta may be of use in a long-range program. High concentrations of spores applied to very small scattered plots may introduce the microsporidian into the Crambus population. From these foci, the disease may spread by natural means. In areas where Nosema infesta is known to occur, the disease is chronic in nature and apparently is passed from generation to generation via the egg. Infected larval populations cause little damage to lawns because the parasitized larvae are greatly weakened by the presence of the microsporidian and lose their vigor. 


\section{BACILLUS THURINGIENSIS}

In 1911, Berliner, in Germany, reported the discovery of a disease of the larva of the Mediterranean flour moth, Ephestia kuhniella, caused by a sporeforming bacterium. In 1915 he described this organism and named it Bacillus thuringiensis. Mattes, in 1927, isolated from diseased larvae of the Mediterranean flour moth a spore-forming bacterium which he reported to be Bacillus thuringensis. Smith, Gordon, and Clark (1946) and Steinhaus (1951) agree that the organism isolated by Mattes and also one described by Chorine (1929) as Bacillus thuringiensis are apparently the same as that described

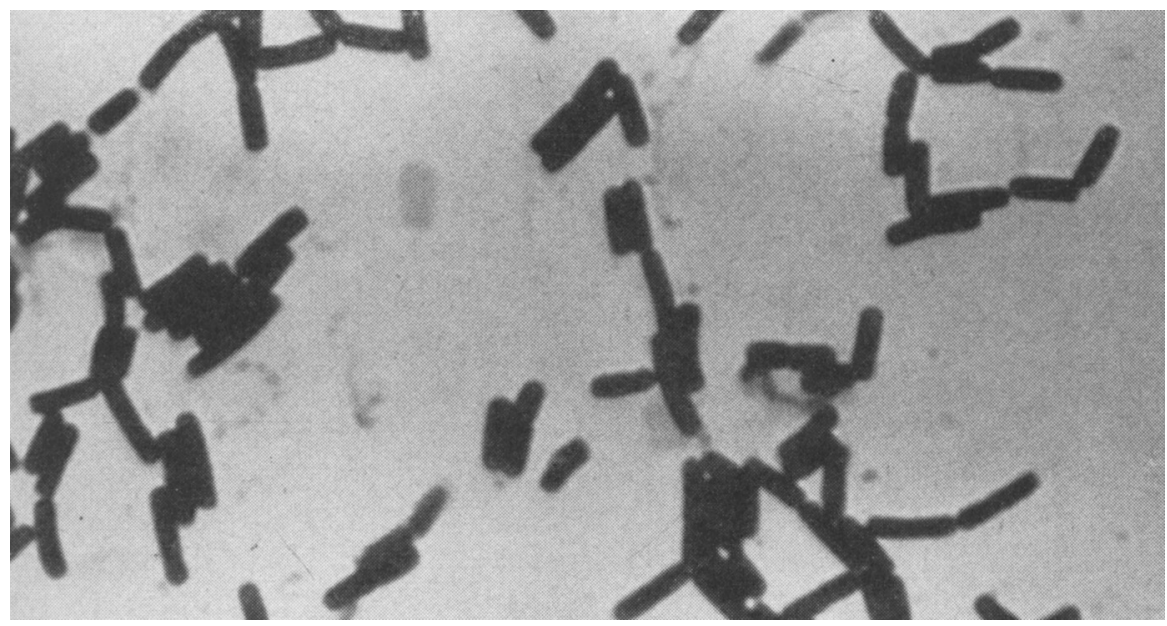

Fig. 2. Vegetative form of Bacillus thuringiensis Berliner.

by Berliner and that Mattes' misspelling of the specific name undoubtedly was unintentional. Metalnikov and Chorine (1929a) isolated from diseased larvae of the Mediterranean flour moth a spore-forming bacterium which they named Bacterium ephestiae. This organism was found to be the same as Bacillus thuringiensis by Ellinger and Chorine (1930).

According to Smith, Gordon, and Clark (1946), the descriptions of Bacillus thuringiensis by Berliner, by Mattes, and by Chorine correspond to the common soil bacterium B. cereus Frankland and Frankland except for the statement by Chorine that mannitol was fermented. Steinhaus (1951) states that $B$. thuringiensis, although culturally and morphologically similar to $B$. cereus, has the property of being pathogenic for certain insects while most strains of typical B. cereus do not consistently show such pathogenicity. Citing a similar situation existing between $B$. cereus, usually saprophytic, and $B$. anthracis Cohn emend. Koch, the causative agent of anthrax, Steinhaus suggests that the name $B$. thuringiensis should be retained for the present. He considers $B$. thuringiensis as a species closely related taxonomically to $B$. cereus and $B$. anthracis, differing primarily by being pathogenic for certain insects and in having spores that lie obliquely in the sporangium. 
The strain of Bacillus thuringiensis used in the experiments for this report was obtained by Steinhaus in 1942 from N. R. Smith, who had received it from J. R. Porter in 1940. Porter in 1936 had obtained the organism from O. Mattes in Germany. It is considered by Steinhaus to be the same strain isolated from diseased larvae of the Mediterranean flour moth by Mattes in 1927.

Several workers have tried Bacillus thuringiensis as a biological control agent against various pest insects. Berliner (1915) briefly discusses the possible use of $B$. thuringiensis in the control of the Mediterranean flour moth in granaries and flour mills. He suggests that the incorporation of bacterial spores with the grain and mill products could be an effective way of suppressing the pest. Shepherd (1924) reports the use of B. thuringiensis for the control of a cosmopolitan bran beetle, Echocerus cornutus (Fabricius) in Germany. Husz (1928, 1929, 1930, 1931), in Hungary, reported the European corn borer, Pyrausta nubilalis (Hübner), to be susceptible to the bacillus and indicated favorable results from spore dusts and sprays in field tests against this insect. Metalnikov and Chorine $(1929 a, b)$, in laboratory tests, also found the bacillus to be pathogenic for the European corn borer, as well as for larvae of Porthetria dispar (Linn.), Aporia crataegi Linn., and Vanessa urticae (Linn.). Laboratory and field tests were conducted with B. thuringiensis against the European corn borer by Metalnikov, Hergula, and Strail $(1930 a, b ; 1931)$, Chorine $(1930 a, b ; 1931)$ and Metalnikov, Ermolaev, and Skobaltzyn (1930). Steinhaus (1951) found the bacillus to be highly virulent for the alfalfa caterpillar, Colias philodice eurytheme Boisduval, and conducted preliminary field tests. Further field tests against the alfalfa caterpillar using B. thuringiensis were made by C. G. Thompson (unpublished data).

The method used to produce Bacillus thuringiensis spore material is similar to that described by Steinhaus (1951). The bacillus was grown on nutrient agar in 6-liter Povitsky bottles. In the preparation of spore material for field tests, the yield from 500 Povitsky bottles was 335 grams of dried spore powder, or about 0.7 gram per bottle.

\section{Laboratory Experiments with Bacillus thuringiensis}

Tests were conducted in the laboratory to determine the virulence of Bacillus thuringiensis for the sod webworm. The first attempt to infect sod webworms with the bacillus was made against second-and third-instar larvae. In this test, the Crambus larvae were set up in groups of 5 to a Petri dish. In each dish were placed fresh grass clippings. Two groups of larvae were maintained as controls. Two dishes were sprayed with a $B$. thuringiensis spore suspension of unknown concentration and two dishes were dusted with pure spore powder. The results are presented in table 3.

A second test was made against fourth- and fifth-instar sod webworms. The larvae were set up in groups of 5 to a Petri dish. Fresh grass clippings were placed in each dish. Three groups of larvae were maintained as controls. A Bacillus thuringiensis spore suspension was prepared by mixing 0.5 gram of spores in $50 \mathrm{ml}$ of distilled water. One dish was sprayed with the suspension for about 1 second (light dose). A second dish was sprayed for about 
2 seconds (medium dose) and a third dish for about 3 seconds (heavy dose). The results are presented in table 4 . They indicate that heavy dosages of bacterial spores may be required to cause high mortality in fourth- and fifthinstar larvae in the shortest possible time.

TABLE 3

EFFECT ON SECOND- AND THIRD-INSTAR CRAMBOS BONIFATELLUS LARVAE OF SPRAYED AND DUSTED BACILLUS THURINGIENSIS SPORES: LABORATORY EXPERIMENTS

\begin{tabular}{|c|c|c|c|c|c|c|c|c|c|}
\hline \multirow[t]{2}{*}{ Treatment } & \multirow{2}{*}{$\begin{array}{l}\text { Num- } \\
\text { ber of } \\
\text { larvae } \\
\text { tested }\end{array}$} & \multicolumn{2}{|c|}{$\begin{array}{l}\text { Larvae alive } \\
\text { after: }\end{array}$} & \multicolumn{2}{|c|}{$\begin{array}{c}\text { Larvae } \\
\text { disappeared; } \\
\text { counts after: }\end{array}$} & \multicolumn{2}{|c|}{$\begin{array}{l}\text { Larvae dead } \\
\text { of other } \\
\text { causes; counts } \\
\text { after: }\end{array}$} & \multicolumn{2}{|c|}{$\begin{array}{l}\text { Larvae dead of } \\
\text { B. thuringiensis } \\
\text { infection; } \\
\text { counts after: }\end{array}$} \\
\hline & & 1 day & 3 days & 1 day & 3 days & 1. day & 3 days & 1 day & 3 days \\
\hline Spore suspension. & 10 & 10 & 0 & 0 & 1 & 0 & 4 & 0 & 5 \\
\hline Spore dust....... & 10 & 4 & 0 & 0 & 0 & 3 & 1 & 3 & 3 \\
\hline None (control)... & 10 & 10 & 10 & 0 & 0 & 0 & 0 & 0 & 0 \\
\hline
\end{tabular}

TABLE 4

EFFECT ON FOURTH- AND FIFTH-INSTAR CRAMBUS BONIFATELLUS LARVAE OF LIGHT, MEDIUM, AND HEAVY SPRAYINGS OF BACILLUS THURINGIENSIS SPORES: LABORATORY EXPERIMEN'TS*

\begin{tabular}{|c|c|c|c|c|c|c|c|c|c|c|c|c|c|c|c|c|c|}
\hline \multirow[t]{2}{*}{ Dosage } & \multirow{2}{*}{$\begin{array}{l}\text { Num- } \\
\text { ber of } \\
\text { larvae } \\
\text { tested }\end{array}$} & \multicolumn{4}{|c|}{$\begin{array}{l}\text { Larvae alive } \\
\text { after: }\end{array}$} & \multicolumn{4}{|c|}{$\begin{array}{l}\text { Larvae disappeared; } \\
\text { counts after: }\end{array}$} & \multicolumn{4}{|c|}{$\begin{array}{l}\text { Larvae dead of other } \\
\text { causes; counts after: }\end{array}$} & \multicolumn{4}{|c|}{$\begin{array}{l}\text { Larvae dead of } \\
B . \text { thuringiensis } \\
\text { infection; } \\
\text { counts after: }\end{array}$} \\
\hline & & $\begin{array}{c}1 \\
\text { day }\end{array}$ & $\begin{array}{l}3 \\
\text { days }\end{array}$ & $\begin{array}{c}5 \\
\text { days }\end{array}$ & $\stackrel{7}{\text { days }}$ & $\begin{array}{c}1 \\
\text { day }\end{array}$ & $\begin{array}{c}3 \\
\text { days }\end{array}$ & $\begin{array}{c}5 \\
\text { days }\end{array}$ & $\begin{array}{c}7 \\
\text { days }\end{array}$ & $\begin{array}{c}1 \\
\text { day }\end{array}$ & $\begin{array}{c}3 \\
\text { days }\end{array}$ & $\begin{array}{c}5 \\
\text { days }\end{array}$ & $\begin{array}{c}7 \\
\text { days }\end{array}$ & $\begin{array}{c}1 \\
\text { day }\end{array}$ & $\begin{array}{c}3 \\
\text { days }\end{array}$ & $\begin{array}{c}5 \\
\text { days }\end{array}$ & $\begin{array}{c}7 \\
\text { days }\end{array}$ \\
\hline Light.... & 5 & 5 & 1 & 0 & $\ldots \dagger$ & 0 & 0 & 0 & . & 0 & 4 & 1 & .. & 0 & 0 & 0 & $\cdots$ \\
\hline Medium. & 5 & 5 & 2 & 1 & 0 & 0 & 0 & 0 & 0 & 0 & 1 & 1 & 1 & 0 & 2 & 0 & 0 \\
\hline Heavy........ & 5 & 4 & 0 & $\ldots \dagger$ & . & 0 & 1 & & . & 0 & 0 & . & & 1 & 3 & .. & .. \\
\hline None (control) & 15 & 14 & 14 & 13 & 13 & 0 & 0 & 1 & 0 & 1 & 0 & 0 & 0 & 0 & 0 & 0 & 0 \\
\hline
\end{tabular}

* Observations were made each day, but counts are given for 2-day intervals.

$\dagger$ Test discontinued after all the larvae had died or disappeared.

\section{Greenhouse Experiments with Bacillus thuringiensis}

The greenhouse experiments were preliminary in nature and were set up in lieu of actual field tests because the sod-webworm populations did not build up in nature during the 1951 season. Conditions for testing the bacillus against Crambus larvae were made as similar to those in nature as facilities would permit. Twenty 12 by 18 inch flats of Kentucky bluegrass were placed in a small nonheated greenhouse. Twenty laboratory-reared fourth- and fifthinstar Crambus larvae were put on each flat. Since the area of each flat is $11 / 2$ square feet, 20 larvae per flat exceeds the 100 larvae per square yard established by Bohart (1947) as the economic level of sod-webworm populations. Each flat was ringed with Tanglefoot to trap any larvae attempting to leave the grass. 
Because of limited space for preparing grass flats and conducting experiments and the availability of only a moderate number of Crambus larvae, no replicates were possible. Five flats were used as unsprayed controls. The other fifteen flats were divided into three test groups of five flats. All groups were sprayed with a water suspension of Bacillus thuringiensis spores, but

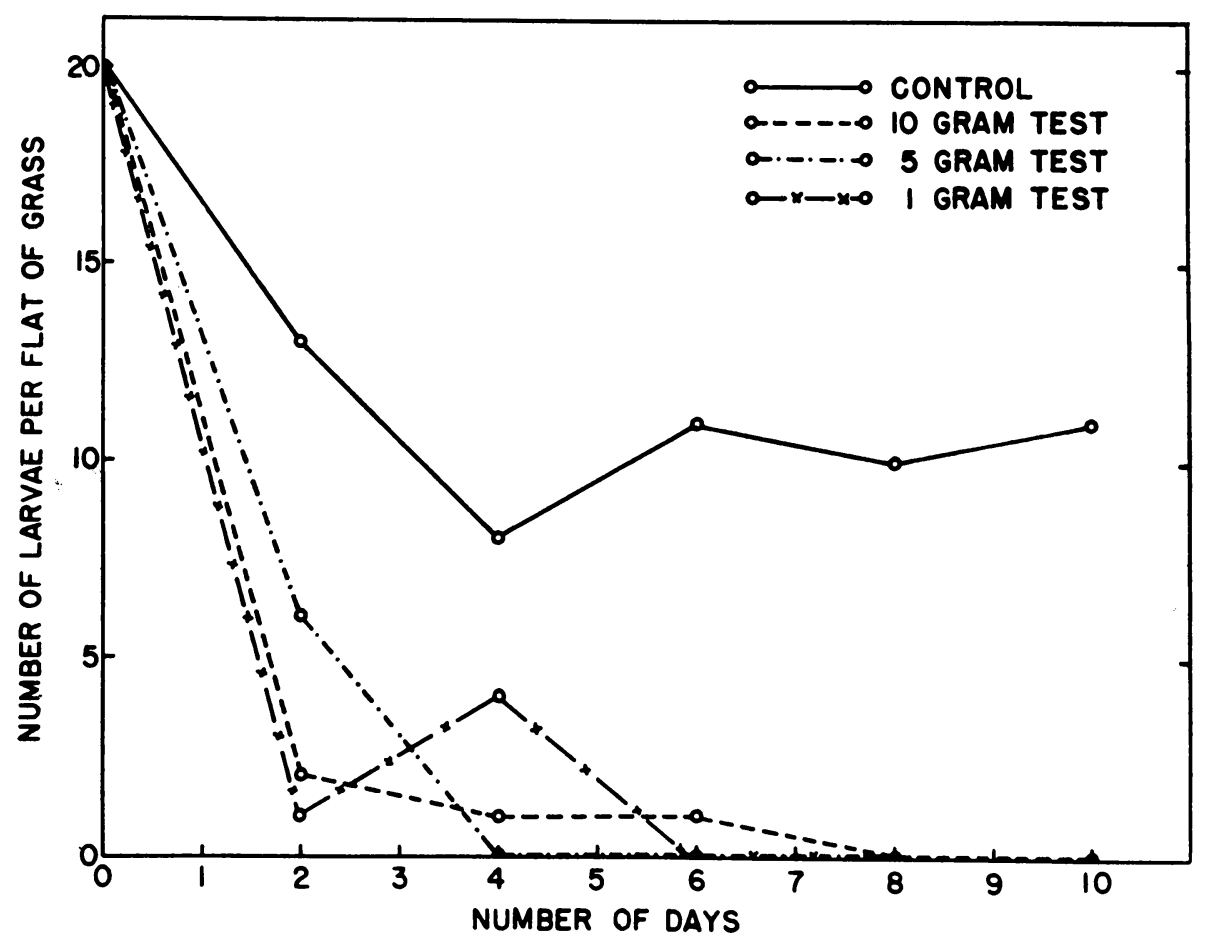

Fig. 3. The number of living Crambus bonifatellus larvae per flat of grass in the test (bacillus-treated) flats and the control (untreated) flats of Bacillus thuringiensis greenhouse experiment 1 . The amounts given for the tests are grams of spores per 100 square yards of lawn.

at different concentrations. The concentrations used were, per $21 / 2$ gallons of water, 10 grams, 5 grams, and 1 gram of spore powder. Application of each spray was made with a Hudson garden sprayer at the rate of $21 / 2$ gallons of spray to 100 square yards of lawn.

Single flats from the control and the three test groups were treated with weak pyrethrum solutions (about 1 quart of 0.04 per cent water miscible pyrethrum per flat) on the second, fourth, sixth, eighth, and tenth days after application of the sprays. The number of larvae recovered were counted and recorded. The results are presented in figure 3.

Not too great differences were evident between the three concentrations of spores used in the test. It should be noted that these concentrations per 100 square yards of lawn are considered to be high, but their use was considered advisable in this first simulated field test. 
A second greenhouse experiment was set up in the same way except that fifteen flats were used, and each flat was inoculated with 40 Crambus larvae. Five flats were reserved as untreated controls. The other ten were sprayed with a Bacillus thuringiensis spore suspension, five flats at 1 gram and five at $0.1 \mathrm{gram}$ of spores to $2 \frac{1}{2}$ gallons of water. As before, application of each

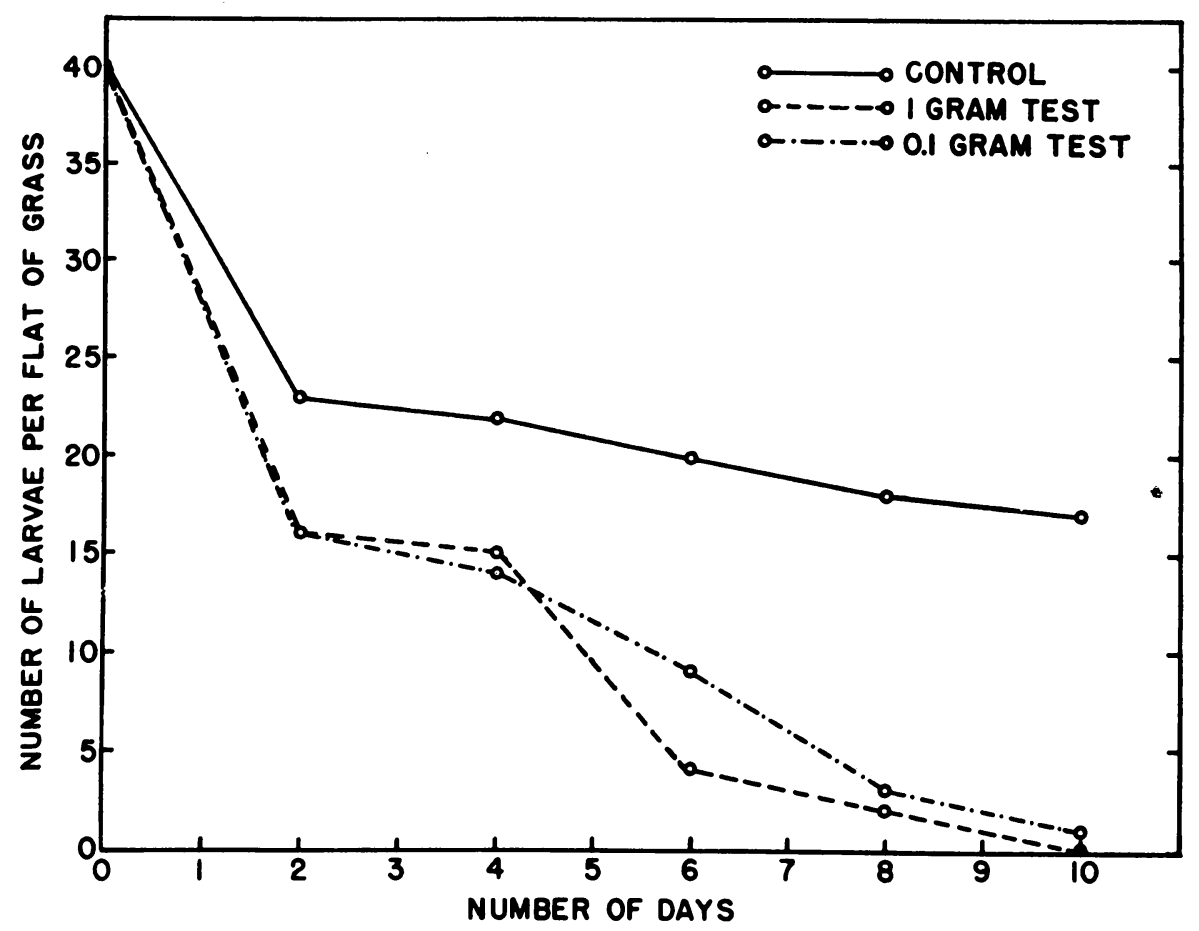

Fig. 4. The number of living Crambus bonifatellus larvae per flat of grass in the test (bacillus-treated) flats and control (untreated) flats of Bacillus thuringiensis greenhouse experiment 2. The amounts given for the tests are grams of spores per 100 square yards of lawn.

spray was made with a Hudson garden sprayer at the rate of $21 / 2$ gallons of spray to 100 square yards of grass.

Single flats from the control and the two test groups were treated with weak pyrethrum solutions on the second, fourth, sixth, eighth, and tenth days after application of the sprays. The number of larvae recovered were counted. The results are presented in figure 4 . This second experiment, utilizing the smallest spore concentration ( 1 gram per 100 square yards) of the first experiment and also a 0.1 gram concentration, gave results rather similar, but not so clear-cut, as those in the first. The two experiments indicate that $B$. thuringiensis may be of value as a biological agent in the control of the sod webworm. 


\section{TWO STRAINS OF BEAUVERIA BASSIANA}

The fungus Beauveria bassiana (Balsamo) is the cause of one of the common "muscardine" diseases, white muscardine, in which the fruiting bodies arise on the exterior of the insect, forming a thick covering. The bodies of the insects infected with the fungus are transformed into white mummies. White muscardine, since it is so easily recognized, was the first acknowledged disease of the silkworm, Bombyx mori (Linn.). Until 1835 the disease was considered to be noncontagious in nature.

Bassi (1835) was the first to show that the disease is contagious and of parasitic origin. He showed that muscardine was caused by a fungus that multiplied in and on the body of the silkworm. Balsamo, according to Steinhaus (1949), studied and described the fungus, giving it the name Botrytis bassiana. Audouin $(1837 a, b)$ observed that the disease was not peculiar to the silkworm and that many other insect species were susceptible.

Beauverie (1911) studied the muscardine fungus, comparing it with another closely related species (Botrytis effusa Beauverie) found on silkworms. He showed that the two species possessed common properties and suggested that a new group be created to include them. It was Vuillemin (1912) who created the genus Beauveria with the species bassiana as the type. Clements and Shear (1931) have placed the genus Beauveria in synonymy with Phymatotrichum, but most authorities retain the former name.

According to Lefebvre (1931b), the fungus grows well, at an optimum temperature of about $28^{\circ} \mathrm{C}$, on most of the artificial media used to cultivate fungi. It characteristically produces a flat, mealy, chalky, pulverulent growth. Sporulation takes place in from 3 to 7 days. When the spore is placed in water it becomes swollen in 24 to 48 hours and puts out one or more slender thin-walled germ tubes. About 32 hours later the germ tubes extend up to 80 microns in length. When conidia are abundantly produced, they are borne in compact globose heads on the main hyphal branches or on short laterals that are usually at right angles to the main axis. Branching is frequently repeated, forming compact heads.

One of the first attempts to use Beauveria bassiana as a biological control agent was made by Tangl (1893) who tried to use the fungus against larvae of the nun moth, Lymantria monacha Linn. His laboratory experiments were successful but the field tests gave negative results.

Considerable study has been made of the possibility of utilizing Beauveria bassiana for controlling the European corn borer. Metalnikov and Toumanoff (1928) and Toumanoff (1933) found the corn borer to be very susceptible to the fungus in Europe. Lefebvre $(1931 a, b)$ reported a laboratory outbreak of $B$. bassiana in larvae of the corn borer imported to the United States from Manchuria. He studied the fungus and made limited field tests, which indicated that the organism was a potential controlling agent of the corn borer. Bartlett and Lefebvre (1934) conducted field experiments against the corn borer in eastern United States. They indicated that larvae in the field were readily susceptible to attack by the fungus. Further field tests were conducted in Canada by Stirrett, Beall, and Timonin (1937), and by Beall, Stirrett, and Conners (1939). 
Steyaert (1935) attempted to use Beauveria bassiana to control the coffee berry beetle, Cryphalus (Stephanoderes) hampei (Ferrari), in the Belgian Congo. Jaynes and Marucei (1947) conducted successful laboratory and field tests with the fungus against larvae of the codling moth, Carpocapsa pomonella (Linn.) in New Jersey. Populations of the Mexican bean beetle in New York were effectively controlled by the fungus, according to Dresner (1949).

The fungi used in this research problem are considered to be two different strains of Beauveria bassiana (Balsamo). One strain was isolated from dead

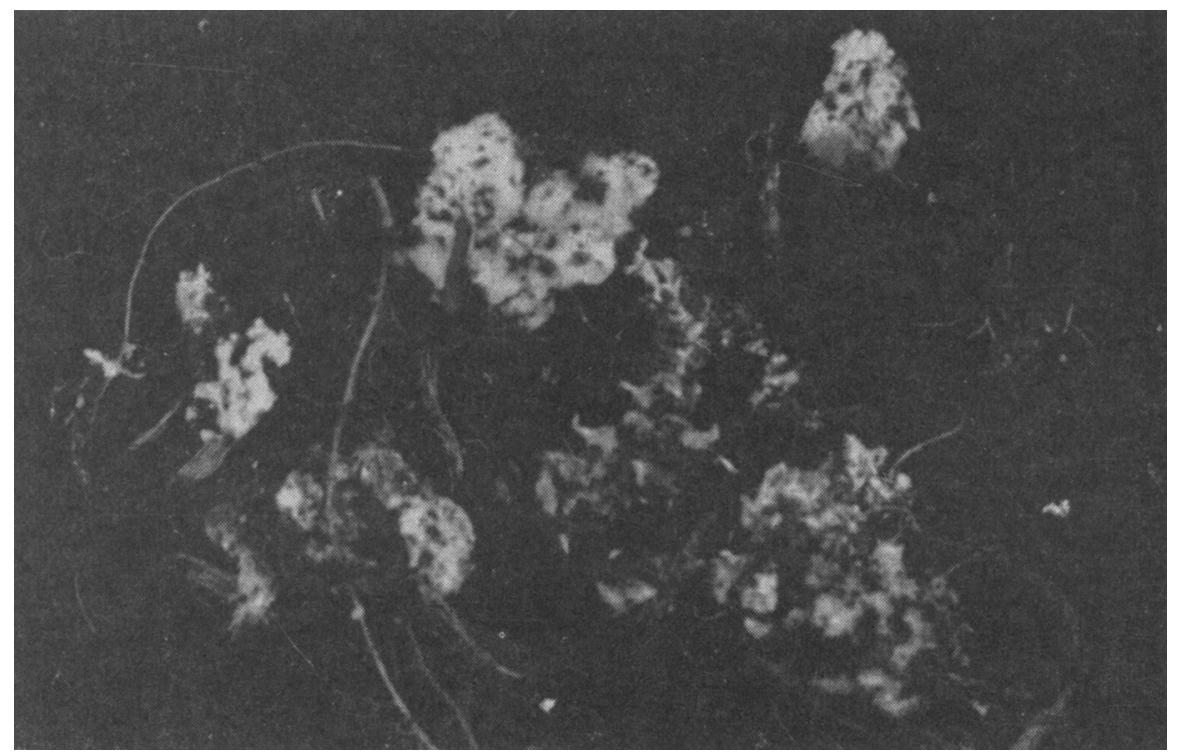

Fig. 5. Mummified larvae of an unidentified species of Crambus from Oregon killed by Beauveria bassiana. The fungus strain from Crambus sp. was isolated from this material.

larvae of the European corn borer, Pyrausta nubilalis (Hübner), received during 1950 by the Laboratory of Insect Pathology (Department of Biological Control, University of California) from K. D. Arbuthnot of the U. S. Department of Agriculture, European Corn Borer Research Laboratory, Ankeny Field Station, Des Moines, Iowa (see Steinhaus, 1952). The other was isolated from dead larvae of an unidentified species of Crambus received during 1950 from B. G. Thompson, Division of Zoology, Oregon State College, Corvallis, Oregon (fig. 5). This fungus was confirmed as Beauveria bassiana by D. M. MacLeod of the Laboratory of Insect Pathology, Division of Entomology, Canadian Department of Agriculture.

The two fungi are identical in most respects, differing only slightly in certain characteristics. The color of the culture and spore of the strain from Crambus is slightly darker than that of the corn borer strain. Although artificial media requirements appear to be the same, the culture growth of the Crambus strain is slightly more elevated. According to C. G. Thompson (unpublished data), cultures of the corn borer strain mutate readily while 
cultures of the Crambus strain have never been observed to mutate. The Crambus strain is more pathogenic to the sod webworm and less effective against other hosts than the strain of Beauveria bassiana from the corn borer.

\section{Production of Beauveria bassiana Spores}

The fungus Beauveria bassiana (Balsamo) has been produced in quantity for field experiments by several workers. Bartlett and Lefebvre (1934) produced fungus spores in various types of Petri dishes and large galvanized trays. To produce a greater quantity of spore material for more extensive field experiments, they used a steam-sterilized culture cabinet similar in design to that described by Rorer (1913). Cornmeal mush was found to be a suitable medium for growing the fungus in trays.

Stirrett, Beall, and Timonin (1937) grew the fungus on soy-bean mash in Petri dishes, obtaining a spore yield per plate of from 0.1 to 0.4 gram. Beall, Stirrett, and Conners (1939), also using soy-bean mash in Petri dishes, obtained an average yield of 0.45 gram per plate.

McCoy and Carver (1941) obtained large quantities of spores on moistened wheat bran and then purified them by an air-separation and filtration method. They obtained a yield of about 22 grams of spores per pound of medium. The air-separation method is considered to be impractical because of the danger involved. One attempt to obtain fungus spores by the McCoy-Carver method terminated in a serious spore-dust explosion causing injury to the operator.

Dresner (1949) tried various ways to produce Beauveria bassiana spores in quantity. Unsuccessful methods included Erlenmeyer flask culture, cultivation on live vegetable matter, cultivation on whole seeds, and inoculation of large insects. Large-scale production of spores was accomplished by cultures on various bulk vegetable media in 9-cm Petri dishes. By culturing, collecting spores, and reculturing, Dresner produced spores at the rate of 60 grams per pound of dried beans.

From the Crambus Strain. The strain of Beauveria bassiana from Crambus sp. in Oregon adapted itself very readily to artificial media. The fungus grew readily on various autoclaved media including nutrient agar, potato, oats, cornmeal, wheat bran and wheatmeal. Because of low cost and ease in handling, rolled oats of the common breakfast type was selected for use as the host medium in the production of spores of this fungus strain.

The yield from 100 standard-sized Petri dishes of oat medium was about 14 grams of spores or about 0.14 gram per dish. The yield from 266 large Petri dishes was about 55 grams of spores, or about 0.2 gram per dish.

An attempt was made to reculture the media as suggested by Dresner (1949). Such a procedure resulted in greatly increased contamination of the harvested spores by spores of an Aspergillus sp. which grows readily on the oat medium. The quantity of Beauveria bassiana spores obtained from recultured media was rather small. Therefore, it was considered to be more advantageous to discard the old media after removing the spores and to set up the dishes immediately with fresh media.

From the Corn-Borer Strain. Quantities of spores of the strain of Beauveria bassiana from the European corn borer were produced. The yield from 93 standard-sized Petri dishes was about 13 grams or about 0.1 gram per dish. 
The yield from 51 large Petri dishes was about 35 grams, or about 0.7 gram per dish. About 58 grams of spores were obtained from 227 large $(20 \mathrm{~cm})$ test tubes containing various agar-based media (potato-dextrose agar, potato infusion).

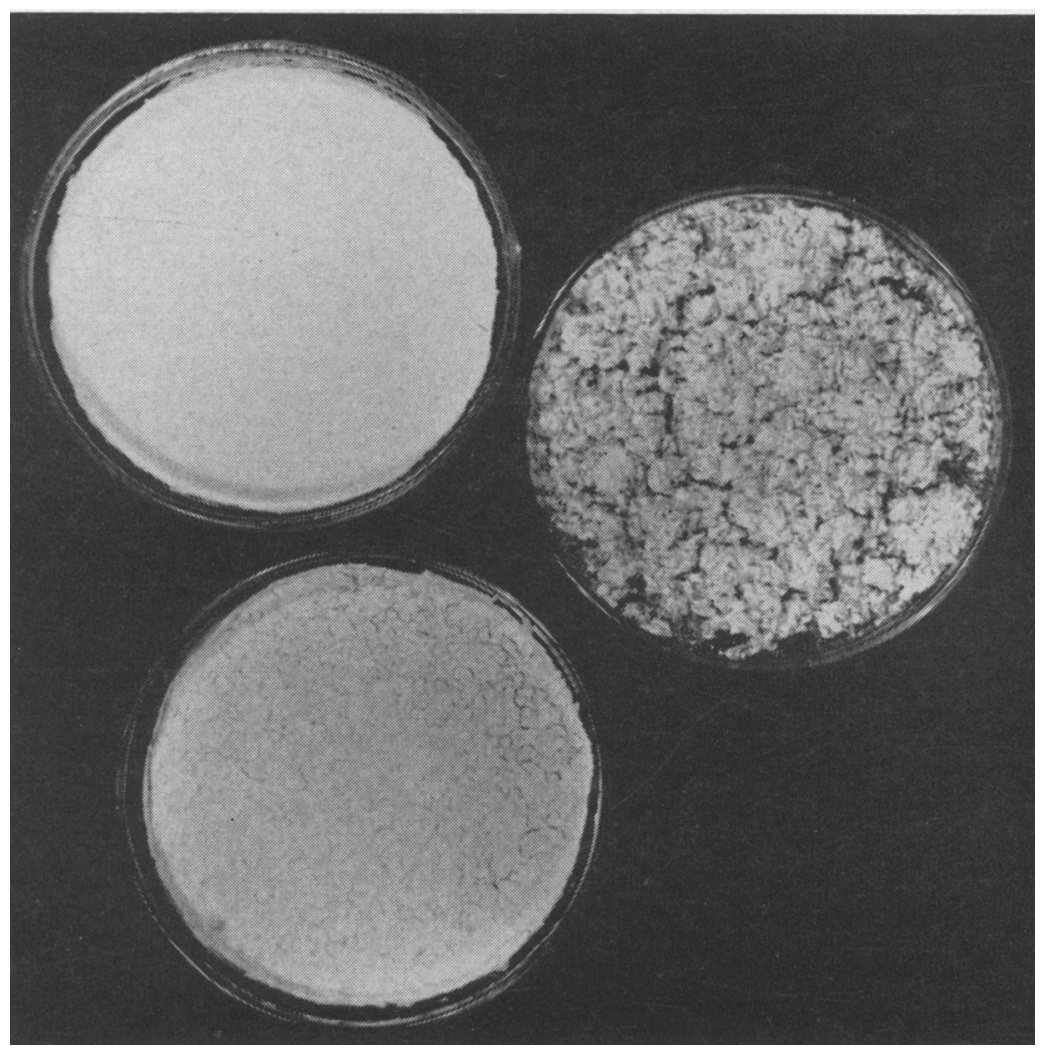

Fig. 6. Colonies of Beauveria bassiana growing on nutrient agar, oatmeal, and wheat bran.

\section{Laboratory Experiments with Beauveria bassiana}

Retention of Virulence. Strains of Beauveria bassiana are known to retain their virulence for extremely long periods when kept on artificial media. An experiment was set up to determine the pathogenicity of spores of the strain from Crambus sp. after long periods of storage in various carriers under different conditions.

Spores of the fungus were set up in (1) tale, (2) Gaviota fertilizer, (3) wheat flour, and (4) no carrier (pure spores). Samples of each carrier and pure spores were stored as follows: (1) room temperature $\left(23^{\circ} \mathrm{C}\right),(2)$ refrigerator $\left(5^{\circ} \mathrm{C}\right)$, and $(3)$ deep freeze $\left(-30^{\circ} \mathrm{C}\right)$.

After a period of nine months, spore samples in each carrier under each storage condition were tested for pathogenicity for the sod webworm. Two 
hundred sixty Crambus bonifatellus larvae were set up in groups of 10 per carton. Two groups were reserved as controls. Spores from each of the different carrier-storage methods were dusted on two groups of larvae. At the end of a 10-day period, the cartons were examined. The results of this test are presented in table 5 .

Pathogenicity to Fggs and First-Instar Larvae. To determine the effect of the Crambus strain of Beauveria bassiana on the eggs and first-instar larvae of Crambus bonifatellus, three Petri dishes were set up, each containing 20 fertile sod-webworm eggs on a damp blotter. One dish was reserved as

TABLE 5

RETENTION OF VIRULENCE OF BEAUVERIA BASSIANA SPORES AFTER NINE MONTHS' STORAGE

Spores of the Crambus strain of the fungus were stored in several carriers and under various conditions, then were dusted on 2 groups of 10 Crambus bonifatellus larvae for each combination of carrier and storage condition

\begin{tabular}{|c|c|c|c|}
\hline \multirow{2}{*}{ Carrier } & \multicolumn{3}{|c|}{ Percentage mortality of larvae* } \\
\hline & At $23^{\circ} \mathrm{C}$ & At $5^{\circ} \mathrm{C}$ & At $-30^{\circ} \mathrm{C}$ \\
\hline 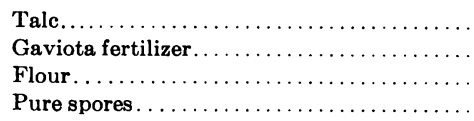 & $\begin{array}{r}0 \\
0 \\
0 \\
30\end{array}$ & $\begin{array}{l}30 \\
60 \\
20 \\
60\end{array}$ & $\begin{array}{l}30 \\
60 \\
50 \\
60\end{array}$ \\
\hline
\end{tabular}

* No larvae were dead in the control group, which was not dusted with spores.

a control. One dish was treated with a very heavy application of spores, accomplished by covering the eggs with pure spore powder, and one with a light dusting of spores, accomplished by shaking a spore-contaminated camel's-hair brush over the eggs.

Six days later, all of the eggs had hatched; the fungus evidently has no effect on the egg. The heavy protective shell apparently prevents the penetration of the egg by the hyphal tube of the fungus. Within 3 days after hatching, some larvae were dead in all three dishes. Of these some died of a bacterial disease quite common among newly hatched larvae. Other dead larvae in the two test dishes showed evidence of external mycelial growth. This growth was much heavier on the dead larvae in the group treated with the heavy application of spores.

By the end of 7 days after eclosion, all of the remaining larvae in the heavydose dish were dead and covered with white mycelium. Only one larvae remained alive in the group lightly dusted with spores. The dead larva in this dish were covered with white mycelium. Five larvae remained alive in the control group and none of the dead larvae was covered with mycelium.

Virulence to Early-Instar Larvae. Laboratory experiments were conducted to determine the virulence of Beauveria bassiana for second- and third-instar larvae of the sod webworm. The first set of two tests was carried out with the strain of the fungus isolated from Crambus sp.

In the first test, four Petri dishes were set up, with 5 Crambus larvae in 
each. Fresh grass was placed in each dish daily. Two dishes were reserved as controls, one test dish was lightly dusted with spores with a hand aspirator, and the other was given a heavy coating of them by the same method.

The procedure in the second test was similar, except that six dishes of 5 larvae were set up, three dishes were reserved as controls, and three different

TABLE 6

EFFEC'TS OF DUSTING SECOND- AND THIRD-INSTAR CRAMBUS BONI$F A T E L I D S$ LARVAE WITH VARIOUS DOSAGES OF SPORES OF TWO STRAINS OF BEADVERIA BASSIANA: LABORATORY FXPERIMENTS

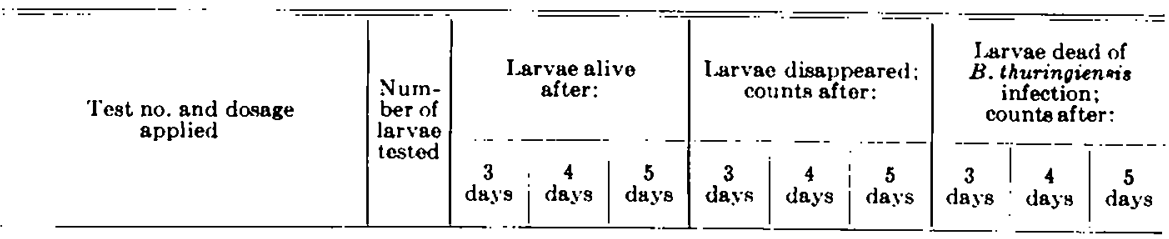

Tests with Crambus strain of Beauveria bassiana

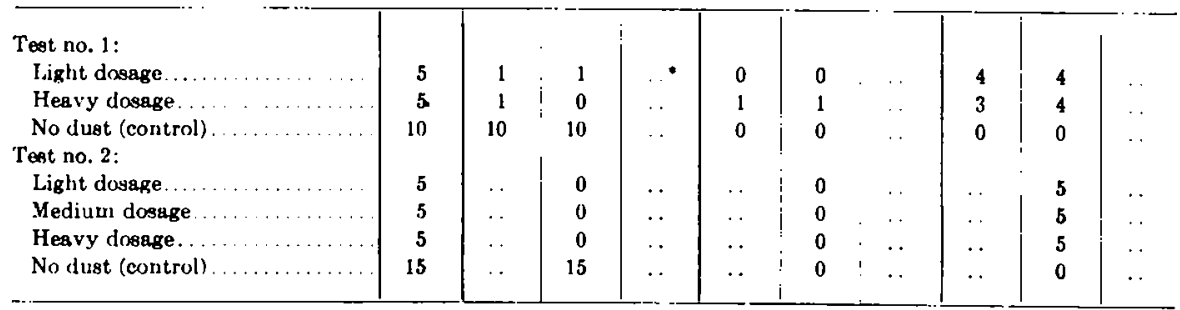

Tests with corn-borer strain of Beauveria bassiana

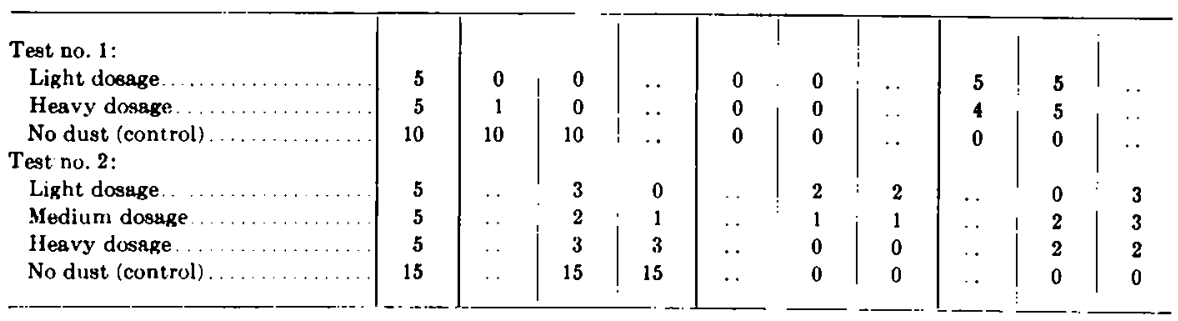

- Blanks indicate no observations were made in a given test at this time.

dosages of spores were used on the three test dishes. The dosage was roughly determined by the number of squeezes of the bulb of a small hand aspirator: one dish was given one squeeze; the second, two; and the third, three. No determination was made of the number of spores applied to a unit area.

The results of both tests are presented in the upper section of table 6 . The data indicate that in laboratory tests against early-instar larvae, the concentration of fungus may be of less importance than the thoroughness of spore dispersion. The use of a hand aspirator insures an even dispersion of spores over the inner surfaces of a container.

In a second set of tests, the strain of Beauveria bassiana isolated from the European corn borer was similarly tested against second- and third-instar larvae. The methods in each test were the same as in the corresponding one 
with the Crambus strain. The results with the corn-borer strain are given in the lower section of table 6 . The corn-borer strain appeared to be about as effective against these early-instar larvae as the Crambus strain; and the data similarly show no significant differences due to the dosages used.

Virulence to Late-Instar Larvae. Laboratory experiments, with both strains of the fungus were also carried out with fourth- and fifth-instar Crambus larvae. Six Petri dishes were set up, each containing 5 larvae, for each strain. Fresh grass clippings were placed in each dish. Three dishes in

TABLE 7

EFFECTS OF DUSTING FOURTH- AND FIFTH-INSTAR CRAMBUS BONIFATELLUS LARVAE WITH VARIOUS DOSAGES OF SPORES OF TWO STRAINS OF BEAUVERIA BASSIANA: LABORATORY EXPERIMENTS*

\begin{tabular}{|c|c|c|c|c|c|c|c|c|c|c|c|c|c|}
\hline \multirow[t]{2}{*}{ Dosage } & \multirow{2}{*}{$\begin{array}{l}\text { Num- } \\
\text { ber of } \\
\text { larvae } \\
\text { tested }\end{array}$} & \multicolumn{4}{|c|}{ Larvae alive after: } & \multicolumn{4}{|c|}{$\begin{array}{l}\text { Larvae disappeared } \\
\text { or dead } \\
\text { of other causes; } \\
\text { counts after: }\end{array}$} & \multicolumn{4}{|c|}{$\begin{array}{l}\text { Larvae dead } \\
\text { of } B \text {. bassiana } \\
\text { infection; } \\
\text { counts after: }\end{array}$} \\
\hline & & $\stackrel{3}{\text { days }}$ & $\begin{array}{c}7 \\
\text { days }\end{array}$ & $\begin{array}{c}10 \\
\text { days }\end{array}$ & $\begin{array}{c}14 \\
\text { days }\end{array}$ & $\begin{array}{c}3 \\
\text { days }\end{array}$ & $\begin{array}{c}7 \\
\text { days }\end{array}$ & $\begin{array}{c}10 \\
\text { days }\end{array}$ & $\begin{array}{c}14 \\
\text { days }\end{array}$ & $\begin{array}{c}3 \\
\text { days }\end{array}$ & $\begin{array}{c}7 \\
\text { days }\end{array}$ & $\begin{array}{c}10 \\
\text { days }\end{array}$ & $\begin{array}{c}14 \\
\text { days }\end{array}$ \\
\hline
\end{tabular}

Test with Crambus strain of Bexuveria bassiana

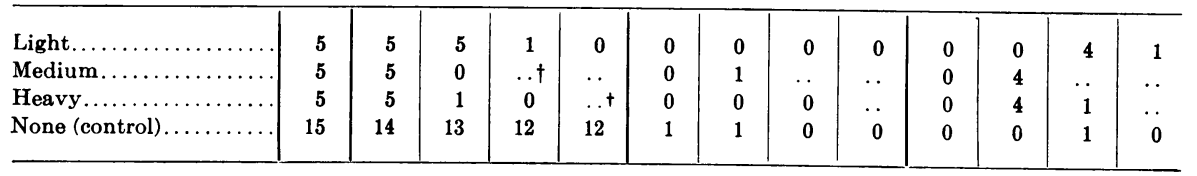

Test with corn-borer strain of Beauveria bassiana

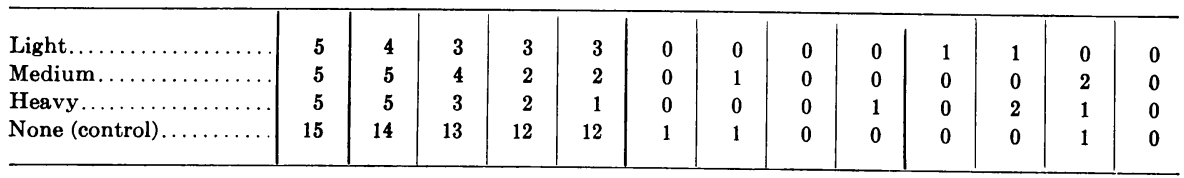

* For purpose of simplification only selected data are given.

$\dagger$ Test discontinued after all the larvae had died or disappeared.

each set were maintained as controls. Spores were dusted on the larvae in the three test dishes for each strain, in three concentrations as described for the second test in each set of the preceding experiments. The results are presented in table 7 .

The length of time required for the fungus to kill the fourth-and fifthinstar larvae is somewhat longer than for the early-instar Crambus. Apparently the larger larvae are more resistant to infection. The strain isolated from the European corn borer was less effective against the late-instar larvae than the fungus strain from Crambus sp.

\section{Greenhouse Experiments with Beauveria bassiana}

Spore-Suspension Spray. Greenhouse experiments similar to those with Bacillus thuringiensis were set up to test the two strains of Beauveria bassiana. Duplicate experiments were carried out for the two strains. In each, twenty 12 by 18-inch flats of Kentucky bluegrass were set up in a small non- 
heated greenhouse. After the grass had been elipped, 20 laboratory-reared fourth-instar Crambus larvae were added to each flat. The rim of each flat was covered with 'langle foot to trap any larvae attempting to leave the grass.

With each strain, five flats were reserved as unsprayed controls. The other fifteen flats were divided into three test groups of five flats each. All were sprayed with a spore suspension prepared by mixing spore powder, bloodalbumen spreader (used as an emulsifying agent because these spores are not miscible with water), and water, but different concentrations of spore powder

TABLE 8

FFFECT OF SPRAYING FOURTH-INSTAR CRAMBUS BONIFATELLDS IARVAE WITH VARIOUS DOSAGES OF TWO STRAINS OF BEAUVERIA BASSIANA SPORES: GREENHOUSE EXPERIMENT NO. 1

Temperatures at Berkeley, California, during the test ranged from $49^{\circ}$ to $73^{\circ} \mathrm{F}^{*}$ " $^{2} 0$ larvae. were placed in each flat at the beginning of the test; blood-albumen spreader was used as emulsifier.

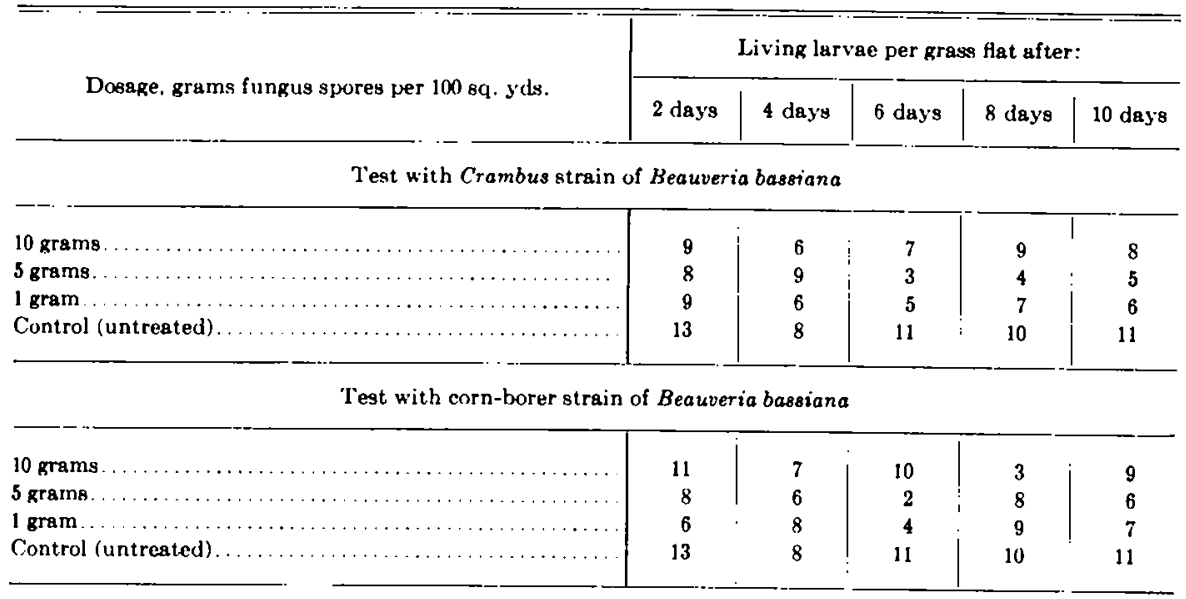

- Data from C.S. Weather Bureau recorda. The greenhouse was unheated.

were used in the three groups: 10 grams, 5 grams, and 1 gram per $21 / 2$ gallons of water. The concentration of blood-albumen spreader was the same in all: 10 grams per $21 / 2$ gallons of water. Application of each spray was made with a Hudson garden sprayer as in the previous experiments, again at the rate of $2 \frac{1}{2}$ gallons of spray to 100 square yards of lawn.

Single flats from the control and each of the three test groups with each strain of fungus were treated with weak pyrethrum solutions on the second, fourth, sixth, eighth, and tenth days after application of the sprays. The number of larvae recovered are shown in table 8.

The results indicate that the fungus had no adverse effect on the Crambus larvae in the flats. No mycelium-covered larval mummies were noticed during a survey of the experimental flats at the end of the test period. The loss of viability of the fungus spores may have been caused by the addition of the blood albumen used as an emulsifying agent.

The spore suspensions used in the experiment had been stored overnight in 


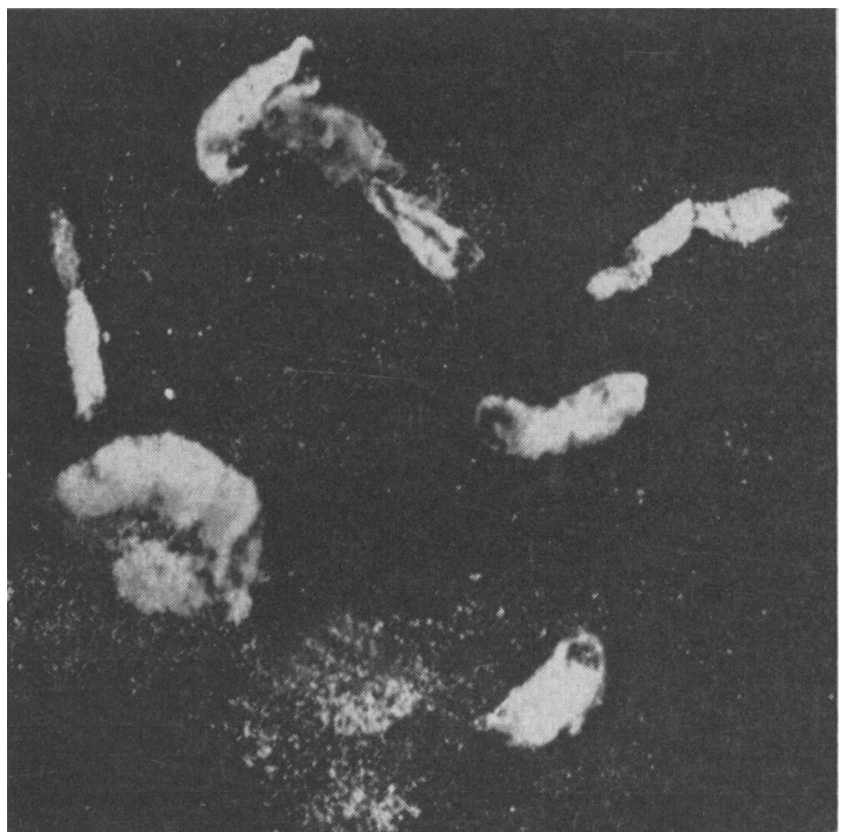

Fig. 7 (above). Mummified larvae of Crambus bonifatellus killed by the strain of Beauveria bassiana from Crambus sp.

Fig. 8 (below). Mummified larvae of Crambus bonifatellus killed by the strain of Beauveria bassiana from the European corn borer.

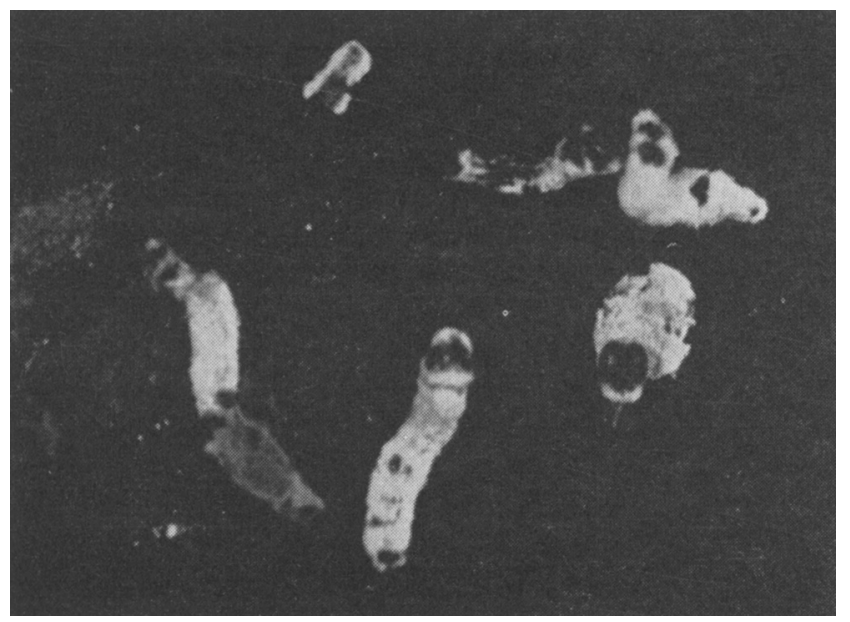


a refrigerator at $5^{\circ} \mathrm{C}$. To determine whether this treatment might have reduced viability, Crambus larvae were tested in the laboratory with freshly prepared spore suspensions and spore suspensions that had been stored overnight under refrigeration. The negative results obtained in both cases indicated that the period of storage is not the viability-reducing factor.

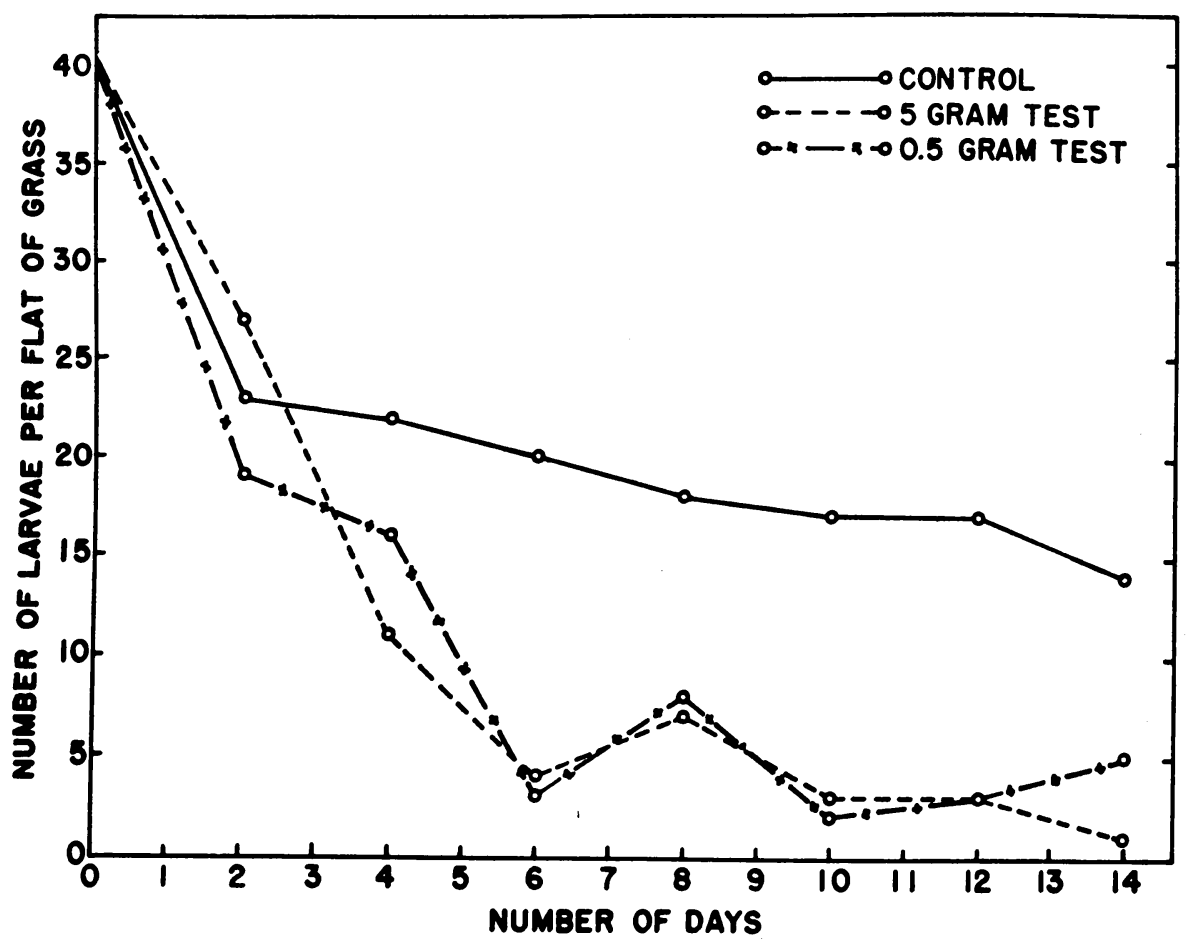

Fig. 9. Number of Crambus bonifatellus larvae per flat of grass in test (fungus-treated) flats and control (untreated) flats of Crambus strain of Beauveria bassiana greenhouse experiment 2 .

Spore-Talc Dust. A second greenhouse experiment was set up in the same way except that twenty-one flats were used for each fungus strain, and each flat was inoculated with $40 \mathrm{Crambus}$ larvae. In each set of twenty-one flats, seven were reserved as untreated controls. The test flats in this experiment were dusted with a spore-talc mixture, seven in each set with a 5 per cent (by weight) and seven with a 0.5 per cent spore dust. Applications of the dusts were made with small aspirators at the rate of 100 grams of dust to 100 square yards of lawn.

Single flats from the control and the two test groups of each strain were treated with weak pyrethrum solutions on the second, fourth, sixth, eighth, tenth, twelfth, and fourteenth days after application of the dusts. The number of larvae recovered were counted. The results with the two strains are presented in figures 9 and 10. This second test, using spore-talc dust, gave more encouraging results than the previous test, using a sprayed spore-water 


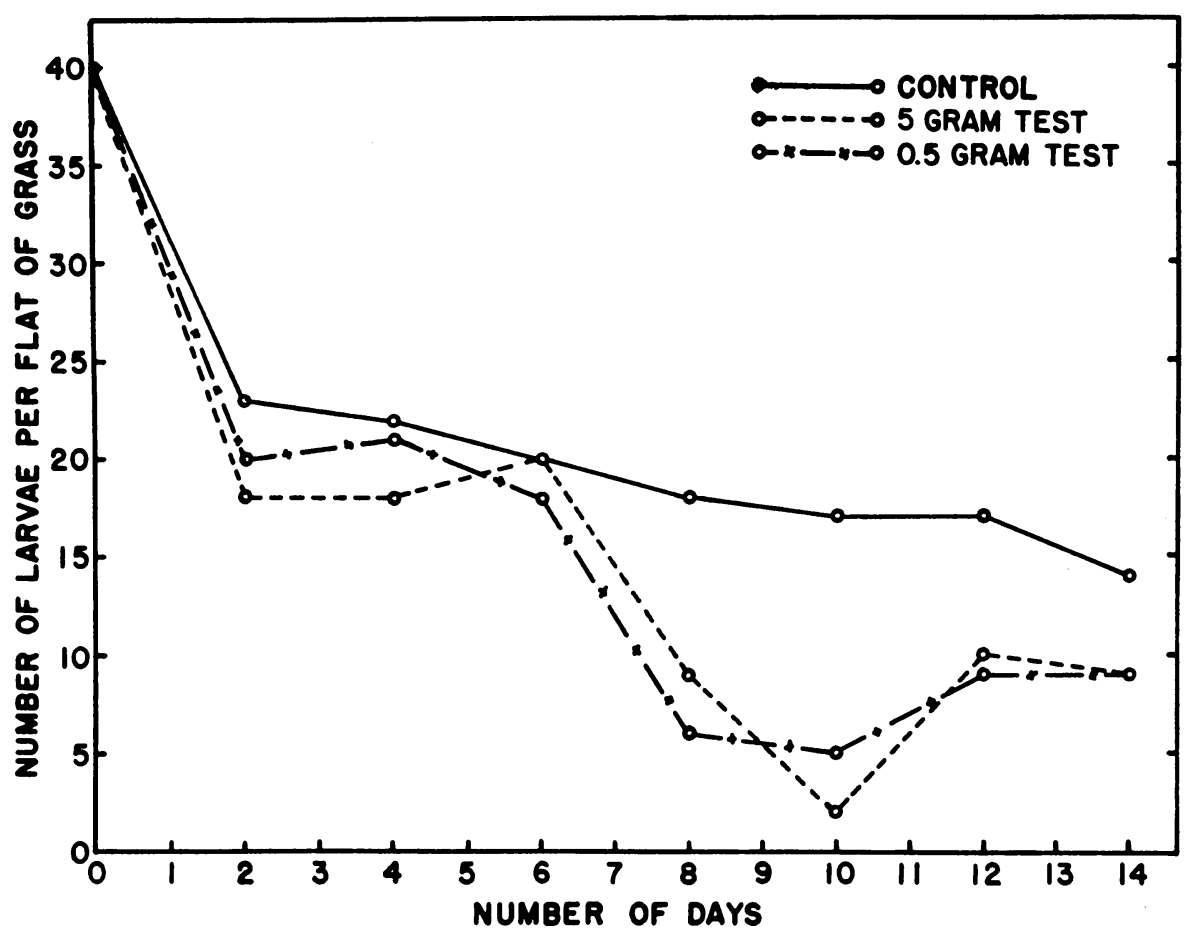

Fig. 10. The number of Crambus bonifatellus larvae per flat of grass in test (fungustreated) flats and control (untreated) flats of Beauveria bassiana (European corn-borer strain) greenhouse experiment 2.

suspension. The two spore concentrations gave quite similar results. In contrast with the previous test, larval mummies were seen in the test flats of both fungus strains after the sixth day.

The results of this test indicate that the corn-borer strain of the fungus, although able to infect and kill some sod webworms, is not as effective as the strain isolated from Crambus sp. This is in agreement with the laboratory tests discussed previously, in which the corn-borer strain was less effective than the Crambus strain against late-instar larvae. 


\section{DISCUSSION AND SUMMARY}

Widespread damage to grasses by lawn moths of the genus Crambus Fabricius has been reported throughout North America since 1929. The efforts made to combat these pests have involved the use of insecticides. Many insecticides have been tested and recommended for use against the crambid larvae, including some of the chlorinated hydrocarbons such as DDT, toxaphene, and chlordane.

Lawn moths are known to have numerous natural enemies including the few reported diseases which have been mentioned previously. Except for the single laboratory experiment by Bohart (1947) using cultures of bacteria isolated from diseased Crambus larvae to infect healthy larvae, no previous efforts have been made to utilize biological agents in the control of the sod webworm.

The ideal microörganism for use as a biological control agent should: (1) display marked pathogenicity toward the insect pest; (2) be easily, rapidly, and inexpensively produced; (3) be easily stored without great loss of virulence; (4) be unharmful to man, beneficial insects, and plants; (5) be easy to handle and apply.

Few pathogens could qualify in all respects as the "ideal" agent. Of the four organisms considered herein for control of the sod webworm, Bacillus thuringiensis most nearly satisfies the requirements, followed by the fungi, the Beauveria bassiana strain from Crambus sp. and the B. bassiana strain from the European corn borer, and the microsporidian, Nosema infesta.

Two of the organisms considered herein were known to be pathogenic for species of Crambus. Nosema infesta was isolated from C. bonifatellus, and one strain of Beauveria bassiana was isolated from dead larvae of an unidentified species of Crambus from Oregon. Bacillus thuringiensis and the European-corn-borer strain of Beauveria bassiana, both of which were known to be pathogenic for many species of insects, were tested in the laboratory to determine their pathogenicity for the sod webworm.

Spore Production. The goal in the production of microörganisms, for use in biological control, is to obtain large quantities of the resistant stage (usually the spore stage). Few obstacles are encountered when an organism will grow readily on artificial media without loss of virulence. Such was the ease in the production of spores of Bacillus thuringiensis and the two strains of Beauveria bassiana. These organisms easily adapt themselves to a saprophytic existence on artificial media.

The problems of production increase when the microörganism will grow only on or within a living host. Nosema infesta is an obligate endoparasite, as are all of the Microsporidia. Two insects, the sod webworm, Crambus bonifatellus, and the fiery skipper, Hylephila phylaeus, appeared to offer the greatest potential from the standpoint of spores produced per insect. Unfortunately, the larvae of these insects were difficult to mass-produce. It was necessary, therefore, to use other less-productive hosts (the potato tuberworm and the buckeye caterpillar) in order to obtain enough spore material for limited field tests.

Storing Spores. The most efficient method of storing infective material 
varies with the organism. The strains of Beauveria bassiana produced spores which were harvested as a dry powder. Fungus spores must be kept dry to prevent germination. The spores of Bacillus thuringiensis were harvested in a water suspension and were easily dried and triturated to a spore powder. The spores of both organisms have been reported to survive for several years in dry storage.

Nosema infesta spores were obtained by grinding infected larvae in water and filtering through cheesecloth to remove as much of the host material as possible. Since the microsporidian spores do not survive for long when dry, they must be kept in a water suspension and stored in a refrigerator or deep freeze. Spores of Nosema can be expected to lose their viability if kept for longer than six months, regardless of the method of storage.

Nosema infesta. Nosema infesta is a very slow-acting organism. Crambus larvae are able to survive for some time even when heavily parasitized. Very few of the heavily infected individuals are able to complete the life cycle. On the other hand, lightly infected insects are able to complete their development and reach the adult stage. It is apparent that heavy dosages of infective material, applied when the Crambus larvae are quite small, are necessary to kill any of the larvae present in field plots of grass. Whether or not the application of dosages of spores will establish the microsporidian in a Crambus population is not known. No infected larvae were found in the field-test plots when samples were taken during the year after the tests were conducted.

Because of the difficulties in producing quantities of infective material and the heavy concentrations of spores required in field applications, Nosema infesta may be ruled out as a possible agent in the control of the sod webworm.

Beauveria bassiana. Both strains of Beauveria bassiana were equally effective in laboratory tests against early-instar sod webworms. The fungus strain isolated from Crambus sp. appeared to be more effective against older larvae. In greenhouse tests, the two fungus strains were able to infect and kill crambid larvae when spores were dusted on flats of grass. The Crambus strain appeared to be slightly more effective in these tests although high mortality was not obtained in either case. Spores of $B$. bassiana do not mix readily with water; consequently a water suspension of the spores cannot be used without the addition of a wetting agent. One series of tests with both fungus strains, using a spore suspension containing blood albumen as a wetting agent, gave negative results. The loss of viability of the fungus spores may have been caused by the addition of the blood albumen.

High humidity and favorable temperatures are required by the fungi for spore germination and subsequent infection of the host through the body wall. Such conditions were easily obtained in the laboratory. In the greenhouse tests, the damp condition of the grass flats maintained the proper humidity. It is possible that the daily temperatures of the Berkeley, California area, when the tests were conducted, were too low for satisfactory germination of the fungus spores, thereby reducing the effectiveness of the pathogen.

Bacillus thuringiensis. Bacillus thuringiensis appears to be the most effective of the organisms tested against the sod webworm. The bacillus is quite pathogenic for the crambid larvae. In laboratory tests, it was found to be the 
fastest-acting organism, with larval deaths noted as soon as 1 day after application of the infective material. In the greenhouse tests, almost 100 per cent mortality was noted in the test populations. The bacillus was very easy to handle in greenhouse applications since the spores mix readily with water. A very uniform spore suspension was obtained by agitating the suspension in a Waring blender. Since spore dusts were successfully used in laboratory infectivity tests, it is probable that dusting may be applicable in field tests. Such attempts would require more thorough grinding of the spore powder than for preparation of spore suspensions. The fact that this bacillus is not limited by humidity requirements that restrict the fungi gives it a greater potential for field control of the sod webworm.

Effects on Beneficial Insects and Man. It is not known whether the microorganisms considered are harmful to beneficial insects associated with lawns. Of concern would be the effect on bees and the varied insect parasites of the lawn pests.

None of the pathogens can be considered harmful to man. Steinhaus (1951) reports that oral consumption of a culture of Bacillus thuringiensis by a human volunteer produced no harmful effects. Only in the case of the Crambus strain of Beauveria bassiana has the writer noticed any ill effects from handling the infective materials. Headaches which occurred after harvesting the fungus spores were attributed to the development of a sensitivity from the inhaling of quantities of the spores. According to Dresner (1949), no harmful effects were noted when spores of Beauveria bassiana were inhaled. 


\section{ACKNOWLEDGMENTS}

I am deeply indebted to guidance and assistance given by Dr. Edward A. Steinhaus throughout my research and the writing of this paper, and for aid and advice given by Dr. Clarence G. Thompson in the production and field aspects of this problem. All photographs in this paper were made by Kenneth M. Hughes. I wish to thank Dr. Roderick Craig and Dr. Thomas E. Rawlins, who made helpful criticisms of this paper. 
Ainslee, G. G.

\section{LITERATURE CITED}

1923. Striped sod webworm, Crambus mutabilis Clemens. Jour. Agr. Res. 24:399-414. Audouin, V.

1837a. Recherches anatomiques et physiologiques sur la maladie contagieuse qui attaque les vers à soie, et qu'on désigne sous le nom de Muscardine. Ann. Sci. Nat., 2d sér., Zool., 8:229-45.

1837b. Nouvelles expériences sur la nature de la maladie contagieuse qui attaque les vers à soie, et qu'on désigne sous le nom de Muscardine. Ann. Sci. Nat. 8:257-70.

BartLetT, K. A., and C. L. LeFEBvRE

1934. Field experiments with Beauveria bassiana (Bals.) Vuill., a fungus attacking the Bassi, A. European corn borer. Jour. Econ. Ent. $27: 1147-57$.

1835. Del mal del segno, calcinaccio o moscardino, malattia che affligge $\mathrm{i}$ bachi da seta. Parte 1, Teorica. ix +67 p. Tip. Orcesi, Lodi.

Beall, G., G. M. Stirrett, and I. L. Conners

1939. A field experiment on the control of the European corn borer, Pyrausta nubilalis Hübn., by Beauveria bassiana Vuill. II Sci. Agr. 19:531-34.

BeAuverie, J.

1911. Sur une muscardine du ver à soie non produite par le Botrytis bassiana Bals. Etude du Botrytis effusa sp. n. Rapp. presenté a la Chambre du Commerce de Lyon, Vol. XIV.

BERLINER, E.

1911. Über die Schlaffsucht der Mehlmottenraupe. Ztschr. f. das Gesam. Getreidewesen $3: 63-70$.

1915. Über die Schlaffsucht der Mehlmottenraupe (Ephestia kuhniella Zell.) und ihren Erreger Bacillus thuringiensis, n. sp. Ztschr. f. Angew. Ent. 2:29-56.

BoHART, R. M.

1947. Sod webworms and other lawn pests in California. Hilgardia $17: 267-308$.

Chorine, V.

1929. New bacteria pathogenic to the larvae of Pyrausta nubilalis Hbn. Internatl. Corn Borer Invest., Sci. Rpts. 2:39-53.

1930a. De l'utilisation des microbes entomophytes dans la lutte contre les insectes nuisibles et de la destruction par ces microbes des chenilles de la pyrale du maïs. [Angram] Inst. Bot. R. Univ. Zagrebensis Acta Bot. 5:7-17.

$1930 \mathrm{~b}$. On the use of bacteria in the fight against the corn borer. Internatl. Corn Borer Invest., Sci. Rpts. 3:94-98.

1931. Sur l'utilisation des microbes dans la lutte contre la pyrale du maïs. Inst. Pasteur [Paris] Ann. 46:326-36.

Clements, F. E., and C. L. Shear

1931. The genera of fungi. iv $+496 \mathrm{p} .+58 \mathrm{pl}$. H. W. Wilson, New York, N.Y.

DRESNER, E.

1949. Culture and use of entomogenous fungi for the control of insect pests. Boyce Thompson Institute Contrib. 15:319-35.

Ebeling, W., R. J. Pence, and M. H. Kimball

1947. DDT found promising for control of lawn moth and sod webworms. Pacific Coast Nurseryman 5:4-19.

Ellinger, T., and V. Chorine

1930. Note on the bacteria isolated from Ephestia kühniella Zell. Internatl. Corn Borer Invest., Sci. Rpts. 3:37-38.

Finney, G. L., S. E. Flanders, and H. S. Smith

1947. Mass culture of Macrocentrus ancylivorus and its host, the potato tuber moth. Hilgardia $17: 437-83$.

HALL, I. M.

1952. A new species of Microsporidia from the fawn-colored lawn moth, Crambus bonifatellus (Hulst) (Lepidoptera, Crambidae). Jour. Parasitol. 38:487-91. 
Husz, B.

1928. Bacillus thuringiensis Berl., a bacterium pathogenic to corn borer larvae. Internatl. Corn Borer Invest., Sei. Rpts. 1:191-93.

1929. The use of Bacillus thuringiensis in the fight against the corn borer. Internatl. Corn Borer Invest., Sci. Rpts. 2:99-110.

1930. Field experients on the application of Bacillus thuringiensis against the corn borer. Internatl. Corn Borer Invest., Sci. Rpts. 3:91-93.

1931. Experiments during 1931 on the use of Bacillus thuringiensis Berliner in controlling the corn borer. Internatl. Corn Borer Invest., Sci. Rpts. 4:22.

JAYNeS, H. A., and P. E. MARUCCI

1947. Effect of artificial control practices on the parasites and predators of the codling moth. Jour. Econ. Ent. 40:9-25.

JefFerson, R. N., and C. O. EADS

1951. Control of sod webworms or lawn moths in southern California. So. California Turf Culture 1(1): $1-4$.

1952. Control of sod webworms in southern California. Jour. Econ. Ent. 45:114-18.

LEFEBVRE, C. L.

1931a. A destructive fungous disease of the corn borer. Phytopathology 21:124-25.

1931b. Preliminary observations on two species of Beauveria attacking the corn borer, Pyrausta nubilalis Hübner. Phytopathology 21:1115-28.

MaCoY, E. E., and C. W. CARvER

1941. A method for obtaining spores of the fungus Beauveria bassiana (Bals.) Vuill. in quantity. New York Entomol. Soc. Jour. 49:205-10.

MATTES, $O$.

1927. Parasitäre Krankheiten der Mehlmottenlarven und Versuche über ihre Verwendbarkeit als biologische Bekämpfungsmittel. (Zugleich ein Beitrag zur Zytologie der Bakterien) Gesell. f. Beförd. Gesam. Naturw. Sitzber. Marburg 62:381-417.

Metalnikov, S., and V. ChORINe

$1929 a$. Experiments on the use of bacteria to destroy the corn borer. Internatl. Corn Borer Invest., Sci. Rpts. 2:54-59.

$1929 b$. On the infection of the gypsy moth and certain other insects with Bacterium thuringiensis. A preliminary report. Internatl. Corn Borer Invest., Sci. Rpts. 2:60-61.

Metalnikov, S., J. Ermolaev, and V. Skobaltzyn

1930. New bacteria pathogenic to the larvae of Pyrausta nubilalis Hbn. Internatl. Corn

Borer Invest., Sci. Rpts. 3:28-36.

Metalnikov, S., B. Hergula, and D. M. Strail

$1930 a$. Experiments on the application of bacteria against the corn borer. Internatl. Corn Borer Invest., Sci. Rpts. 3:148-51.

1930b. Utilisation des microbes dans la lutte contre la pyrale du maïs. Acad. des Sci. [Paris] Compt. Rend. 191:738-40.

1931. Utilisation des microbes dans la lutte contre la pyrale du maïs. Inst. Pasteur [Paris] Ann. 46:320-25.

Metalnikov, S., and C. Toumanoff

1928. Recherches expérimentales sur l'infection de Pyrausta nubilalis par des champiNoBLe, W. B. gnons entomophytes. Soc. de Biol. [Paris] Compt. Rend. 98:583-84.

1932. Sod webworms and their control in lawns and golf greens. U. S. Dept. Agr. Cir. 248:1-4.

RORER, J. B.

1913. The use of the green muscardine in the control of some sugar cane pests. Phytopathology $3: 88-92$.

ShePherd, D. 1924. Life history and biology of Echocerus cornutus (Fab.). Jour. Econ. Ent. 17:
$572-77$.

SMITh, N. R., R. E. Gordon, and F. E. Clark

1946. Aerobic mesophilic sporeforming bacteria. U. S. Dept. Agr. Misc. Pub. 559:1-112. 
Steinhaus, E. A.

1949. Principles of insect pathology. $x i+757$ p. McGraw-Hill Book Company, Inc., New York, N.Y.

1951. Possible use of Bacillus thuringiensis Berliner as an aid in the biological control of the alfalfa caterpillar. Hilgardia $20: 359-81$.

1952. Microbial infections in European corn borer larvae held in the laboratory. Jour. Econ. Ent. 45:48-51.

STEYAERT, R. L.

1935. Un ennemi naturel du Stephanoderes, le Beauveria bassiana (Bals.) Vuill. Étude des facteurs ambiants régissant sa pullulation. Inst. Natl. pour l'étude Agron. du Congo Belge Pubs., Ser. Sci. 2:1-46.

StirretT, G. M., and D. A. ArNotT

1932. Observations on the outbreak of sod webworms during the season of 1931. Ent. Soc. Ontario, Ann. Rpt. 62:69-75.

Stirrett, G. M., G. Beall, and M. Timonin

1937. A field experiment on the control of the European corn borer, Pyrausta nubilalis TANGL, F. Hubn., by Beauveria bassiana Vuill. Sci. Agr. 17:587-91.

1893. Bakteriologischer Beitrag zur Nonnenraupenfrage. Forstwiss. Cent. 15:209-30. TOUMANOFF, C.

1933. Action des champignons entomophytes sur la pyrale du maïs (Pyrausta nubilalis Hün). Ann. Parasitol. Humaine et Comparée 11:129-43.

Vuillemin, $\mathrm{P}$.

1912. Beauveria, nouveau genre de Verticilliacées. Soc. Botan. de France Bul. 59:34-40. 

The journal Hilgardia is published at irregular intervals, in volumes of about 600 pages. The number of issues per volume varies.

Subscriptions are not sold. The periodical is sent as published only to libraries, or to institutions in foreign countries having publications to offer in exchange.

You may obtain a single copy of any issue free, as long as the supply lasts; please request by volume and issue number from:

\author{
Publications Office \\ College of Agriculture \\ Berkeley 4, California
}

The limit to nonresidents of California is 10 separate issues on a single order. A list of the issues still available will be sent on request.

In order that the information in our publications may be more intelligible, it is sometimes necessary to use trade names of products or equipment rather than complicated descriptive or chemical identifications. In so doing, it is unavoidable in some cases that similar products which are on the market under other trade names may not be cited. No endorsement of named products is intended nor is criticism implied of similar products which are not mentioned. 